OPEN ACCESS

Edited by:

Amy Rasley,

Lawrence Livermore National Laboratory (DOE), USA

Reviewed by:

Simone Brogi,

University of Siena, Italy Kenichi Morikawa,

Hokkaido University Hospital, Japan

Keke Celeste Fairfax,

Purdue University, USA

${ }^{*}$ Correspondence:

Wanpen Chaicumpa wanpen.cha@mahidol.ac.th

Specialty section:

This article was submitted to

Microbial Immunology,

a section of the journal

Frontiers in Immunology

Received: 04 March 2016 Accepted: 08 August 2016 Published: 26 August 2016

Citation:

Jittavisutthikul S, Seesuay W,

Thanongsaksrikul J, Thueng-in K,

Srimanote $P$, Werner RG and Chaicumpa W (2016) Human

Transbodies to HCV NS3/4A

Protease Inhibit Viral Replication and

Restore Host Innate Immunity.

Front. Immunol. 7:318.

doi: 10.3389/fimmu.2016.00318

\section{Human Transbodies to HCV NS3/4A Protease Inhibit Viral Replication and Restore Host Innate Immunity}

\author{
Surasak Jittavisutthikul,2, Watee Seesuay², Jeeraphong Thanongsaksrikul2,3, \\ Kanyarat Thueng-in ${ }^{2,4}$, Potjanee Srimanote ${ }^{3}$, Rolf G. Werner ${ }^{5}$ and Wanpen Chaicumpa ${ }^{2,3 *}$ \\ ${ }^{1}$ Graduate Program in Immunology, Department of Immunology, Faculty of Medicine Siriraj Hospital, Mahidol University, \\ Bangkok, Thailand, ${ }^{2}$ Department of Parasitology, Faculty of Medicine Siriraj Hospital, Center of Research Excellence on \\ Therapeutic Proteins and Antibody Engineering, Mahidol University, Bangkok, Thailand, ${ }^{3}$ Graduate Program in Biomedical \\ Science, Faculty of Allied Health Sciences, Thammasat University, Pathum-thani, Thailand, ${ }^{4}$ School of Pathology, Institute of \\ Medicine, Suranaree University of Technology, Nakhon Ratchasima Province, Thailand, ${ }^{5}$ Industrial Technology, Faculty of \\ Science, University of Tuebingen, Tuebingen, Germany
}

A safe and effective direct acting anti-hepatitis $\mathrm{C}$ virus $(\mathrm{HCV})$ agent is still needed. In this study, human single chain variable fragments of antibody (scFvs) that bound to HCV NS3/4A protein were produced by phage display technology. The engineered scFvs were linked to nonaarginines (R9) for making them cell penetrable. HCV-RNA-transfected Huh7 cells treated with the transbodies produced from four different transformed $E$. coli clones had reduced HCV-RNA inside the cells and in the cell spent media, as well as fewer HCV foci in the cell monolayer compared to the transfected cells in culture medium alone. The transbodies-treated transfected cells also had up-expression of the genes coding for the host innate immune response, including TRIF, TRAF3, IRF3, IL-28B, and IFN- $\beta$. Computerized homology modeling and intermolecular docking predicted that the effective transbodies interacted with several critical residues of the NS3/4A protease, including those that form catalytic triads, oxyanion loop, and S1 and S6 pockets, as well as a zinc-binding site. Although insight into molecular mechanisms of the transbodies need further laboratory investigation, it can be deduced from the current data that the transbodies blocked the HCV NS3/4A protease activities, leading to the HCV replication inhibition and restoration of the virally suppressed host innate immunity. The engineered antibodies should be tested further for treatment of HCV infection either alone, in combination with current therapeutics, or in a mixture with their cognates specific to other HCV proteins.

Keywords: cell-penetrating antibody (transbody), hepatitis C virus, innate immunity, phage display, NS3/4A protease, qRT-PCR, single chain antibody

\section{INTRODUCTION}

Before 2011, patients with hepatitis C virus (HCV) infection were weekly injected with pegylatedinterferon-alpha combined with daily oral ribavirin (a nucleoside analog), which is a standard-of-care (SOC). The treatment conferred high rate of sustained virologic response (SVR) against HCV of most genotypes by restoring the virally suppressed host innate immunity and restraining the viral load (1). 
However, HCV strains of genotype 1 were relatively refractory to the SOC. Besides, the regimen is prolonged, stringent, and costly, as well as induces severe adverse effects, which are poorly tolerated by a significant fraction of the recipients. During the past decade, intense research has focused on development of direct acting anti-HCV agents (DAAs) that interfere with the functions of several HCV proteins. These are, for examples, inhibitors of NS3/4A protease (e.g., telaprevir, boceprevir, simeprevir, asunaprevir, danoprevir, faldaprevir, paritaprevir); NS5B polymerase (e.g., sofosbuvir, dasabuvir); a protein important for membrane web formation, NS4B [e.g., substituted imidazo(1,2-a) pyrimidines, clemizole, piperazinones]; a regulatory phosphoprotein of the viral replication complex, NS5A (e.g., ombitasvir, daclatasvir, ledipasvir, velpatasvir); or capsid protein (2-10). Also, drugs that inhibit HCV-host protein interaction have been tested $(11,12)$. Presently, several DAAs have received regulatory approval for clinical use, such as protease inhibitors (boceprevir, telaprevir, and semiprevir), polymerase inhibitor (sofosbuvir), and NS5A inhibitor (ledipasvir). Additional DAAs are in various stages of clinical development $(9,13)$. Many new drug regimens, when administered either singly, together with SOC, or in various combinations among themselves, conferred improved SVR rate compared with SOC $(9,13-16)$. However, the challenges that the new drugs are facing include complicated treatment protocols, additional severe side effects, drug-drug interaction, and emergence of drug- and cross-drug-resistant HCV mutants. The new regimens are contraindicated for some groups of patients/ subjects (16-21). Thus, safe and effective DAAs are needed.

Passive immunization (administration of ready-made antibody) has been practiced for prevention/intervention and treatment of diseases since the late eighteenth century (called serum therapy/serotherapy at the time) (22). Nevertheless, the physicochemical properties of the plasma membrane impede accessibility of antibodies to their intracellular targets (such as proteins/enzymes of replicating virus). To circumvent this obstacle, several peptides called cell-penetrating peptides (CPPs) have been developed for delivering antibodies/antibody fragments and a variety of other cargoes (proteins, drugs, nucleic acids, plasmids, and siRNAs) across the plasma membrane into cytosol and also to different subcellular compartments (23-27). Examples of the CPPs are protein transduction domains (such as penetratin, HIV-1 Tat peptide) (28), amphipathic peptides such as protein-rich motif (SAP) (29), and other CPP type, including nonaarginine (R9) and polylysine (30). In our laboratory, cellpenetrable antibodies (transbodies) specific to viral proteins have been prepared by linking the antibody molecules to either penetratin or R9. These fusion proteins readily entered mammalian cells and bound to their respective intracellular targets (31-35).

Usually, an antibody molecule uses several amino acids in the complementarity determining regions (CDRs) to interact with multiple residues/sites of the target, which makes it difficult for the pathogens to escape the antibody binding. On the contrary, pathogens may resist small molecular inhibitors through a single amino acid mutation (21). In this study, cell-penetrable human single chain antibody variable fragments (transbodies) to $\mathrm{HCV}$ protease that inhibit the viral replication and restore the host innate immune response were produced. It is envisaged that a right combination of cell-penetrable human/humanized antibodies that target pivotal enzymes of the HCV, i.e., helicase (31), polymerase $(32,33)$, and protease $(34)$, a strategy similar to the precedent anti-HIV regimen, should be a novel anti-HCV remedy that is safe, genotype independent, and more tolerable to the viral mutation.

\section{MATERIALS AND METHODS}

\section{Recombinant HCV NS3/4A Fusion Protein Production}

The recombinant NS3/4A protein (rNS3/4A) with the HCVinherent serine protease activity was produced from BL21 (DE3) E. coli carrying pET23b ${ }^{+}-N S 3 / 4 A$, as described previously (34). The fusion protein contained 180 amino acids of the $N$-terminal one-third of the NS3 of the genotype 3a HCV linked with residues 21-32 of the NS4A of the same genotype. The recombinant NS3/4A protein cleaved a fluorescent peptide substrate that contained nine amino acids at the protease cleavage site as determined by a continuous fluorescence resonance energy transfer (FRET) assay (34).

\section{Mouse Anti-NS3/4A Polyclonal Antibody}

The experiments received approval from the Siriraj Bio-safety Risk Management Taskforce (SI 2014-004). Three ICR mice (National Laboratory Animal Center, Mahidol University, Nakhonpathom, Thailand) were housed in a shoe-box typed cage under $12 / 12$ light/dark cycle at $23-25^{\circ} \mathrm{C}$ and $55-60 \%$ humidity. Feed and water were supplied ad libitum. The animals were immunized intraperitoneally with three doses at 2-week intervals of $10 \mu \mathrm{g}$ purified recombinant NS3/4A protein mixed with alum (Pierce, USA) at ratio 1:3. After the last booster, the mice were bled and their serum titers were assessed against the homologous antigen by indirect ELISA.

\section{Immunological Methods}

Indirect ELISA was performed as described previously (33) using $1 \mu \mathrm{g}$ of purified $\mathrm{rNS} 3 / 4 \mathrm{~A}$ protein in $100 \mu \mathrm{l}$ of carbonate-bicarbonate buffer, $\mathrm{pH} 9.6$ to coat each well of an ELISA plate. Five percent skim milk in PBS $(300 \mu \mathrm{l} /$ well $)$ was used for blocking the well surface before adding antibody preparations (e.g., serial dilutions of the mouse immune sera, HuscFv preparations) into appropriate wells. Antibody control was either normal mouse serum or lysate of original E. coli. Bovine serum albumin (BSA) served as control antigen and PBS as blank. After incubation, all wells were washed with the PBS containing $0.05 \%$ Tween-20 (PBST). Horseradish peroxidase (HRP)-conjugated anti-immunoglobulin isotype (Southern Biotech, Birmingham, AL, USA) and chromogenic substrate (KPL, Gaitherburg, MD, USA) were used for color development. The enzymatic reaction was stopped by adding $1 \%$ SDS. OD $_{405 \mathrm{~nm}}$ of contents in all wells were determined against blank.

For SDS-PAGE and Western blot analysis (WB), polyacrylamide gel at a desired gel percentage cast in a Mini-PROTEAN- $3^{\circledR}$ Cell System (Bio-Rad, Hercules, CA, USA) was used. Samples prepared in $6 \times$ SDS gel reducing buffer were boiled for $10 \mathrm{~min}$ 
before loading into the gel slots made in the $4 \%$ stacking gel. PageRuler $^{\circledR}$ pre-stained protein ladders (Fermentas, Thermo Fisher Scientific, MA, USA) were included in one or two gel slots as molecular weight marker. Electrophoresis was carried out in Tris-glycine running buffer, $\mathrm{pH} 8.3$, initially at $10 \mathrm{~mA}$ per gel until the bromphenol blue dye font reached the resolving gel; then the electricity was increased to $20 \mathrm{~mA}$ and continued until the dye font reached the lower gel edge. Separated proteins in the gel were either revealed by staining with Coomassie Brilliant Blue G-250 dye or they were electroblotted onto nitrocellulose membrane (NC) for WB. For WB, the blotted NC was blocked either with $3 \%$ BSA or $5 \%$ skim milk in PBS. The blocked NC was then probed with antibody preparation; then the antigen-antibody reactive bands were revealed using alkaline phosphatase (AP)-labeled anti-isotype antibody and AP chromogenic substrate.

\section{Phage Clones That Bound to the rNS3/4A Protein and the Phage Transformed E. coli Clones}

Phage clones bound to the rNS3/4A fusion protein were fished-out from a human $\mathrm{scFv}$ phage display library as described previously (33) using purified rNS3/4A ( $1 \mu \mathrm{g})$ as bait. The rNS3/4A-bound phages were put into HB2151 E. coli bacteria, and the bacteria were spread on a $2 \times$ YT-AG plate. Direct colony PCR (36) was used to screen $E$. coli colonies that carried HuscFv coding genes (huscfvs). Lysates of huscfv-positive E. coli colonies grown in $0.5 \mathrm{mM}$ IPTG-conditioned broth were determined by Western blotting for the presence of the E-tagged-HuscFvs.

\section{Characterization of the Bacterially Derived-HuscFvs}

Spectrometrically standardized soluble HuscFvs in the lysates of transformed HB2151 E. coli clones were tested for binding to the rNS3/4A by indirect ELISA and Western blotting. Original HB2151 E. coli (HB) was used as background binding control in both assays. BSA served as control antigen in the indirect ELISA.

Diversity of the huscfvs sequences of the HB2151 E. coli clones were determined by subjecting the PCR amplified huscfvs to MvaI digestion followed by resolving the cut DNA products in $14 \%$ polyacrylamide gel containing $0.5 \%$ glycerol. Electrophoresis was carried out in TBE buffer at $20 \mathrm{~mA}$ per slab gel. The separated DNA bands were stained by ethidium bromide and the restriction fragment length polymorphism (RFLP) was determined using a Bio Doc-ITTM Imaging System, UVP, USA. CDRs and their respective canonical immunoglobulin framework regions (FRs) of the sequenced huscfvs were predicted using an online Internatioanl ImMunoGeneTics (IMGT ${ }^{\circledR}$ ) Information System.

\section{Generation of Cell Penetrating HuscFvs (Transbodies)}

Because the antibodies must bind to the target inside the HCVinfected cells, they were linked to nonaarginine (R9), which is a cell-penetrating peptide, as follow: the huscfvs were amplified from the pCANTAB5E phagemids using a Q5 High Fidelity DNA polymerase (Thermo Fisher Scientific). The specific primers were forward-R9-huscfv-LIC: 5'-GGTTGGGAATTGCAACGTCGCCGT
CGCTCGCCGTCGCCGTCGCCGTGCGGCCCAGCCCG GCC-3' and reverse-E-tag-LIC: 5'-GGAGATGGGAAGTCATT AACGCGGTTCCAGCGGATCC- $3^{\prime}$. The reaction mixture contained $15.75 \mu \mathrm{l}$ sterile distilled water, $5.0 \mu \mathrm{l}$ Q 5 reaction buffer $(5 \times), 0.5 \mu \mathrm{dNTP} \operatorname{mix}(10 \mathrm{mM}$ each), forward and reverse primers (10 $\mu \mathrm{M}$ in $1.25 \mu \mathrm{l}$ each), $1.0 \mu \mathrm{l}$ of $h u s c f v$-phagemid template (3 ng DNA template), and 0.25 unit of Q5 Hotstart DNA polymerase. The thermal cycles were first denaturation at $98^{\circ} \mathrm{C}, 30 \mathrm{~s} ; 34$ cycles of denaturation at $98^{\circ} \mathrm{C}$ for $30 \mathrm{~s}$, annealing/extension at $69^{\circ} \mathrm{C}$ for $10 \mathrm{~s}$, and final extension at $72^{\circ} \mathrm{C}, 5 \mathrm{~min}$; and hold at $4^{\circ} \mathrm{C}$, several min. The PCR product was stained with ethidium bromide, verified, and purified from agarose gel using DNA extraction kit (Jena Bioscience, Jena, Germany). The 5'- and 3'- overhangs of the R9-huscfv amplicons were generated by setting up the following reaction mixtures: $9 \mu$ of sterile distilled water, $2 \mu$ l of $5 \times$ LIC buffer, $0.1 \mathrm{pmol}$ of the purified PCR product, and $1 \mu \mathrm{l}$ T4 DNA polymerase and dGTP. The reaction mixtures were kept at $25^{\circ} \mathrm{C}$ for $5 \mathrm{~min}$ and stopped by adding $0.6 \mu \mathrm{l}$ of $0.5 \mathrm{M}$ EDTA. Annealing of the DNA products with 15 base pairs (bp) 5 '-overhang to the pLATE52 vector containing complementary overhang was performed by mixing $1 \mu \mathrm{l}$ of the vector and $60 \mathrm{ng}$ ( $0.02 \mathrm{pmol}) \mathrm{LIC}$ ready vector (Thermo Fisher Scientific). The mixtures were kept at $25^{\circ} \mathrm{C}$ for 5 min before putting into JM109 E. coli by heat-shock method. The transformed E. coli clones carrying the recombinant pLATE52-R9-huscfv plasmids were screened by PCR using the pLATE52 specific primers, i.e., LIC forward sequence: 5'-TAATACGACTCACTATAGGG-3' and LIC reverse sequence: 5'-GAGCGGATAACAATTTCACACAGG-3'. The PCR reaction mixture was: $12.7 \mu \mathrm{l}$ sterile distilled water, $2 \mu \mathrm{l}$ PCR buffer $+\mathrm{KCl}$ (10×), $1.2 \mu \mathrm{l} 25 \mathrm{mM} \mathrm{MgCl}, 2 \mu \mathrm{ldNTP} \operatorname{mix}(10 \mu \mathrm{M}$ each), $1 \mu \mathrm{l}$ $(10 \mu \mathrm{M})$ each of LIC primers, and 0.5 unit of Taq polymerase.

The pLATE52-R9-huscfv were extracted from the PCR positive clones, purified, put in Rosetta ${ }^{\mathrm{TM}} 2$ (DE3)-competent cells (Novagen, Schwalbach, Germany), and spread onto selective LB agar plates supplemented with $100 \mu \mathrm{g} / \mathrm{ml}$ ampicillin and $34 \mu \mathrm{g} /$ $\mathrm{ml}$ chloramphenicol (Calbiotech, Spring Valley, CA, USA) (LBAC agar). The sibling $E$. coli colonies grown on the agar plates were randomly picked and screened for the presence of the pLATE52-R9-huscfv plasmids by PCR using the pLATE52 primers. The Rosetta ${ }^{\mathrm{TM}} 2$ (DE3) bacteria with the pLATE52-R9-huscfv plasmids were cultured in $0.5 \mathrm{mM}$ IPTG-conditioned broth. The induced bacterial cells were collected and R9-HuscFvs in their homogenates were determined by SDS-PAGE and Western blotting using anti-6× His as the $\mathrm{R} 9-\mathrm{HuscFv}$-detection reagent. The clones that expressed the R9-HuscFvs (with $6 \times$ His and T7 tags at the $N$-terminal and E-tag at the $C$-terminal) were kept as stocks in $20 \%$ glycerol at $-80^{\circ} \mathrm{C}$ until use.

\section{Large-scale Production, Purification, and Refolding of the Cell Penetrating HuscFvs}

The Rosetta ${ }^{\mathrm{TM}} 2$ (DE3) E. coli clones carrying the pLATE52-R9huscfv were grown in $2 \times \mathrm{YT}-\mathrm{AC}$ broth at $37^{\circ} \mathrm{C}$ with shaking at $250 \mathrm{rpm}$ for $16 \mathrm{~h}$. Ten milliliters of the overnight culture were inoculated into $250 \mathrm{ml}$ of $2 \times$ YT-AC broth in a 2-liter flask and incubated with shaking aeration at $37^{\circ} \mathrm{C}$ until $\mathrm{OD}_{600 \mathrm{~nm}}$ was approximately $0.8-0.9(\sim 3 \mathrm{~h})$. The culture was added with IPTG 
(final concentration of $1 \mathrm{mM}$ ), incubated at $30^{\circ} \mathrm{C}$ for $6 \mathrm{~h}$, and centrifuged at $5,000 \times g$ at $4^{\circ} \mathrm{C}$ for $20 \mathrm{~min}$. To prepare the bacterial inclusion bodies (IBs), each $2 \mathrm{~g}$ of the $E$. coli wet pellets were lysed with $10 \mathrm{ml}$ of BugBuster ${ }^{\mathrm{TM}}$ protein extraction reagent (Novagen, Schwalbach, Germany) and $20 \mu \mathrm{l}$ of Lysonase ${ }^{\mathrm{TM}}$ bioprocessing reagent (Novagen). The preparation was kept at $25^{\circ} \mathrm{C}$ on a rotator for $20 \mathrm{~min}$ and centrifuged at $8,000 \times g$ at $4^{\circ} \mathrm{C}$ for $30 \mathrm{~min}$. IB in the pellet was washed twice with Wash-100 reagent and once with Wash-114 reagent with shaking at high speed for 40 min and centrifuged. The IB was then washed with Wash-Solvent reagent and Milli Q water on ice also with vigorous shaking and centrifuged.

For HuscFv refolding, $5 \mathrm{ml}$ of buffer [ $50 \mathrm{mM}$ CAPS, pH 11.0; $0.3 \%(\mathrm{w} / \mathrm{v}) \mathrm{N}$-Lauryl sarcosine; and $1 \mathrm{mM} \mathrm{DTT}]$ were added to reconstitute $5 \mathrm{mg}$ of purified IB and kept at $4^{\circ} \mathrm{C}$ for $16 \mathrm{~h}$. After dissolving completely, the protein was loaded into the Slide-ALyzer $^{\circledR} 2 \mathrm{~K}$ Dialysis Cassettes G2 (Thermo Fisher Scientific), and the cassette was subjected to dialysis against $750 \mathrm{ml}$ of a refolding buffer (20 mM imidazole, $\mathrm{pH} 8.5$, supplemented with $0.1 \mathrm{mM}$ DTT) at $4^{\circ} \mathrm{C}$ with slow stirring. After $3 \mathrm{~h}$, the buffer was changed to fresh refolding buffer, and the dialysis was continued for $16 \mathrm{~h}$. The refolded protein was subsequently dialyzed against a dialysis buffer (20 mM imidazole without DTT) with slow stirring at $4^{\circ} \mathrm{C}$ for $16 \mathrm{~h}$. The preparation was filtered through a $0.2-\mu \mathrm{m}$ low protein binding Acrodisc ${ }^{\circledR}$ Syringe Filter (Pall, NY, USA) and kept in $30^{\circ} \mathrm{C}$ water-bath for additional $2 \mathrm{~h}$ before adding with $60 \mathrm{mM}$ trehalose. Protein concentration of the refolded HuscFvs was measured (Pierce ${ }^{\circledR}$ BCA Protein Assay), while quality and purity of the proteins were determined by SDS-PAGE and protein staining. The antibodies were tested for binding to the homologous antigen (rNS3/4A) by indirect ELISA.

\section{Cell Penetrating Ability of the R9-HuscFvs, Their Intracellular Target Binding, and Toxicity}

The experiments involving HCV of this study received approval from the Siriraj Bio-safety Risk Management Taskforce. The pJFH-1 (GenBank AB047639), which carried a full-length HCV genotype 2a cDNA, was used for production of HCV RNA, as described previously $(32,33)$. Briefly, the plasmid was cut with $X b a I$ endonuclease and transcribed using a T7-transcription kit (MEGAscript ${ }^{\circledR}$, Ambion, Foster City, CA, USA). Ten micrograms of JFH-1 RNA were put in Huh7 cells $\left(4 \times 10^{6}\right.$ cells) suspended in $0.4 \mathrm{ml}$ of reduced serum medium (Opti-MEM, Invitrogen, USA) by means of electroporation; complete DMEM containing 10\% heat-inactivated fetal bovine serum (Hyclone, USA) and antibiotics was immediately added to the electroporated cells, which were then distributed onto individual cover slips $\left(2 \times 10^{4}\right.$ cells/slip $)$ placed in wells of a 24-well tissue culture plate After incubating at $37^{\circ} \mathrm{C}$ in $5 \% \mathrm{CO}_{2}$ incubator overnight and rinsed with sterile PBS, the cells were replenished with $500 \mu$ l complete DMEM containing $10 \mu \mathrm{g}$ of individual R9-HuscFvs. After $1 \mathrm{~h}$, culture supernatants were removed; the cells were washed with PBS, fixed with $1 \%$ Triton X-100, 30 min; blocked with 3\% BSA; and washed. Rabbit anti-6× His polyclonal antibody (Abcam, Cambridge, UK) (1:500) was added to the cells and incubated at $37^{\circ} \mathrm{C}$ for $1 \mathrm{~h}$, washed, and 1:1000 mouse anti-NS3/4A polyclonal antibody was added. After $1 \mathrm{~h}$, the cells were washed and added with goat anti-rabbit Alexa Flour 488 (1:500) and donkey anti-mouse Alexa Flour $^{\circledR} 647$ (Abcam). DAPI (1:5000) (Invitrogen, Carlsbad, CA, USA) was used to stain nuclei. The preparations were kept at $37^{\circ} \mathrm{C}$ for $1 \mathrm{~h}$, and the stained cells were observed under a confocal microscope.

CytoTox $96^{\circledR}$ non-radioactive cytotoxicity (lactate dehydrogenase, LDH) assay kit (Promega, Madison, WI, USA) and Cell Titer-Glo ${ }^{\circledR}$ Luminescent Cell Viability Assay kit (Promega) were used for determining cytotoxicity of the R9-HuscFvs to Huh7 cells. The LDH release assay was performed as described previously (35). Huh7 monolayer in individual wells of a 96-well tissue culture plate $\left(2 \times 10^{4}\right.$ cells/well $)$ were washed with sterile PBS, added with $25 \mu \mathrm{g}$ of R9-HuscFvs in complete DMEM, and incubated for $24 \mathrm{~h}$ at $37^{\circ} \mathrm{C}$ in $5 \% \mathrm{CO}_{2}$ atmosphere. Controls were cells in the medium alone (minimal/spontaneous release) and cells added with $10 \%$ SDS (maximal release) were included. After $24 \mathrm{~h}$, culture supernatants (triplicate wells of each treatment) were collected separately. Fifty microliters of culture fluid were mixed with the assay buffer provided with the kit and kept at $25^{\circ} \mathrm{C}$ for $30 \mathrm{~min}$ under light protection. The reactions were stopped by adding $1 \mathrm{M}$ acetic acid, and $\mathrm{OD}_{490 \mathrm{~nm}}$ was determined. Percent cytotoxicity was (LDH release of test - spontaneous LDH release)/ (Maximal LDH release - spontaneous LDH release) $\times 100(35)$. Percent cell viability was calculated by subtracting 100 with percent cytotoxicity.

For the Luminescent Cell Viability Assay that quantifies the number of viable cells based on the amounts of ATP released by metabolically active cells, Huh7 cells cultured in complete DMEM were seeded into wells of a 96-well opaque tissue culture plates (Corning) $\left(2 \times 10^{4}\right.$ cells/well). After incubating at $37^{\circ} \mathrm{C}$ in $5 \% \mathrm{CO}_{2}$ atmosphere for $24 \mathrm{~h}$, the spent media were removed, and the tested cells were added with $25 \mu \mathrm{g}$ of purified R9-HuscFvs in $100 \mu \mathrm{l}$ complete DMEM. Medium only was added to the control cells (negative control). After keeping at $37^{\circ} \mathrm{C}$ in $5 \% \mathrm{CO}_{2}$ incubator for $48 \mathrm{~h}$, the plate was brought to room temperature $\left(25^{\circ} \mathrm{C}\right)$ for $30 \mathrm{~min}$; the medium in each well was replaced with $100 \mu \mathrm{l}$ of the Glo reagent, kept on an orbital shaker for 2 min, then at room temperature for 10 more min for luminescence stabilization. The luminescence signal of each well was recorded using Synergy ${ }^{\mathrm{TM}}$ H1 Multi-mode Reader (BioTek ${ }^{\circledR}$ ). Luminescence of the well containing medium only served as background luminescence. The percentage of cell viability was (Luminescence of test - Background luminescence)/(Luminescence of negative control - Background luminescence) $\times 100$.

For in vivo toxicity testing of the R9-HuscFv, a protocol of Thai Pharmacopia was followed. Two groups of male BALB/c mice (6-8 weeks old) were used. Each mouse of group $1(n=5)$ was injected intraperitoneally with $25 \mu \mathrm{g}$ of R9-HuscFv/g body weight in $200 \mu \mathrm{l}$ buffer. This antibody dose is higher than those used for passive immunization of human (37). Three more booster doses were given on every alternate day. Control mice (group 2; $n=4$ ) were injected with buffer alone. The animals were observed daily for any sign of morbidity, including ruffled hair, eye and nasal discharge, diarrhea, loss of appetite, and body temperature. Their body weights were determined also. Seven days post-last booster, all mice were bled and their sera were monitored for 
some parameters of blood chemistry including liver enzymes (AP, aspartate aminotransferase, and alanine aminotransferase) and total bilirubin.

\section{Transbody-mediated Inhibition of the HCV Replication}

Huh7 cells transfected with JFH-1 RNA was prepared as above. Aliquots of the transfected cells $\left(2 \times 10^{5}\right.$ cells/well $)$ were added to individual wells of a 12 -well tissue culture plates and kept for $3 \mathrm{~h}$ at $37^{\circ} \mathrm{C}$ in $5 \% \mathrm{CO}_{2}$ incubator. After washing with sterile PBS, the cells were added with $25 \mu \mathrm{g}$ of purified R9-HuscFvs dissolved in complete DMEM. Negative and background inhibition controls were the infected cells added with medium alone and medium containing $25 \mu \mathrm{g}$ of control R9-HuscFv, respectively. Positive inhibition controls were 100 units of pegylated (PEG) interferon $+250 \mu \mathrm{M}$ ribavirin, $0.175 \mu \mathrm{M}$ telaprevir (VX-950) (Selleckem, Houston, TX, USA), and PEG-interferon $+250 \mu \mathrm{M}$ ribavirin $+0.175 \mu \mathrm{M}$ telaprevir. After 5 more days of incubation, total RNAs were extracted from the cells and their spent media (TrizolTM reagent, Invitrogen). Amounts of HCV 5' UTR in all samples were quantified by qRT-PCR (33). Alternatively, culture supernatants of the infected cells in all wells were removed, and the viral foci formed in the respective cell monolayer were enumerated after staining for the HCV core protein (33).

\section{Quantitative Real-time RT-PCR}

The qRT-PCR reaction mixture $(12.5 \mu \mathrm{l})$ was prepared: $6.25 \mu \mathrm{l}$ $2 \times$ Brilliant II SYBR ${ }^{\circledR}$ Green qRT-PCR master mix, $0.5 \mu$ l each of the JFH-1 5' UTR primers, $0.5 \mu \mathrm{l}$ RT/RNS block enzyme, RNA template up to $4.75 \mu \mathrm{l}$ (200-900 ng of standard RNA), and sterile DEPC-treated distilled water to $12.5 \mu \mathrm{l}$. The amplification was carried out using Mx3000P QPCR System (Agilent Technologies) at $42^{\circ} \mathrm{C}$ for $30 \mathrm{~min}, 55^{\circ} \mathrm{C}$ for $30 \mathrm{~min}$, initial denaturation at $95^{\circ} \mathrm{C}$ for $10 \mathrm{~min}$, and 40 cycles of $95^{\circ} \mathrm{C}$ for $30 \mathrm{~s}, 60^{\circ} \mathrm{C}$ for $30 \mathrm{~s}$, and $72^{\circ} \mathrm{C}$ for $30 \mathrm{~s}$. To analyze the dissociation curve, a thermal profile of $95^{\circ} \mathrm{C}$ for $1 \mathrm{~min}$, ramped down to $55^{\circ} \mathrm{C}$ for $45 \mathrm{~s}$ at a speed of $0.5^{\circ} \mathrm{C} / \mathrm{s}$ and ramped up to $95^{\circ} \mathrm{C}$ was carried out. $\mathrm{C}_{t}$ of 10 -fold serially diluted pJFH-1 with full-length HCV genotype 2a cDNA insert, calculated $2.77 \times 10^{7}$ to 0.02 copy numbers, were used for constructing a standard curve. $\log _{10}$ RNA copies/ml of sample was extrapolated from the standard curve. Data of one of the three independent and reproducible experiments are reported herein.

\section{HCV Foci Assay}

Hepatitis C virus foci formed in the JFH-RNA-transfected Huh7 cell monolayer after receiving different treatments were enumerated (34). Briefly, the spent culture fluids of the transfected cells of all treatments were discarded. After washing, the cells were fixed with absolute methanol at $4^{\circ} \mathrm{C}, 15 \mathrm{~min}$; blocked for $1 \mathrm{~h}$ with $10 \%$ $\mathrm{BSA}$ at $37^{\circ} \mathrm{C}$; incubated with mouse anti-HCV core polyclonal antibody; washed; added with AP-conjugated-goat anti-mouse isotype; washed again; and added with AP chromogenic substrate (KPL). Untreated transfected cells and non-transfected (normal) cells were included in the experiments as negative inhibition (maximal number of $\mathrm{HCV}$ foci) and negative foci control, respectively. Numbers of HCV foci in each well were counted under
$40 \times$ magnification using an inverted fluorescence microscope (NIS-Element D version 4.10.0.8310 W/camera, Ti-S Intensilight Ril NIS-D, Nikon, Japan).

\section{Response of the HCV-RNA-transfected Cells after Treatment with the Transbodies and Controls}

After treating the JFH-1 RNA-infected Huh7 cells with various R9-HuscFvs and controls (control R9-HuscFv, PEG-IFN + ribavirin, telaprevir, PEG-IFN + ribavirin + telaprevir, and medium alone), expressions of innate immune response genes (amounts of mRNAs), including TRIF, TRAF3, IRF3, IL-28B, and IFN $\beta$, were determined by qRT-PCR as described previously (34) using GAPDH mRNA for normalization.

\section{Computerized Simulation for Predicting Residues of the HCV NS3/4A Protein Bound by the HuscFvs}

Three-dimensional structure of NS3/4A (PDB ID-1A1R, RCSB database) was retrieved. Tertiary structures of HuscFvs were modeled by subjecting their amino acid sequences to the I-TASSER server (38). The I-TASSER-predicted models were subsequently refined and improved to their nearest native state $(39,40)$. Molecular docking between the NS3/4A 3D and the HuscFv models was performed by ClusPro2.0 server (41). Pymol software (The PyMOL Molecular Graphics System, version $1.3 \mathrm{r} 1 \mathrm{edu}$, Schrodinger, LLC) was used to build and visualize the protein complexes that formed the largest cluster size and the minimal local energy.

\section{Statistical Analysis}

Means and SDs of tests and controls were compared using unpaired $t$-test. $p<0.05$ was considered significantly different.

\section{RESULTS}

\section{Phage-transformed E. coli Clones That Produced HCV NS3/4A-bound HuscFvs and the HuscFv Characteristics}

Fifty-two HB2151 E. coli bacteria infected with the rNS3/4Abound phages that were grown on the selective LB-A agar plate were checked for the presence of huscfvs, and 18 clones (34.6\%) revealed the genes at about $1,000 \mathrm{bp}$ (Figure 1A). After growing these $E$. coli clones under $0.5 \mathrm{mM}$ IPTG-conditioned broth, lysates of 17 clones contained HuscFvs seen as bands at $\sim 27-32 \mathrm{kDa}$ (Figure 1B). The HuscFvs of nine phage-transformed E. coli clones (nos. 6, 10, 21, 25, 27, 30, 34, 41, and 43) gave significant ELISA signal above controls (Figure 1C) and bound to SDSPAGE separated-rNS3/4A by WB (Figure 1D). The nine clones revealed eight different huscfv patterns (eight RFLP types) after cutting with $\mathrm{MvaI}$; clones no. 6, 10, 21, and 25 had patterns $1-4$, respectively; clones no. 27 and 30 had the same pattern 5, while clones no. 34, 41, and 43 showed patterns $6-8$, respectively (Figure 1E). DNA sequences of four clones, i.e., 6, 10, 25, and 34 , had complete coding regions, i.e., sequences of four FRs and 


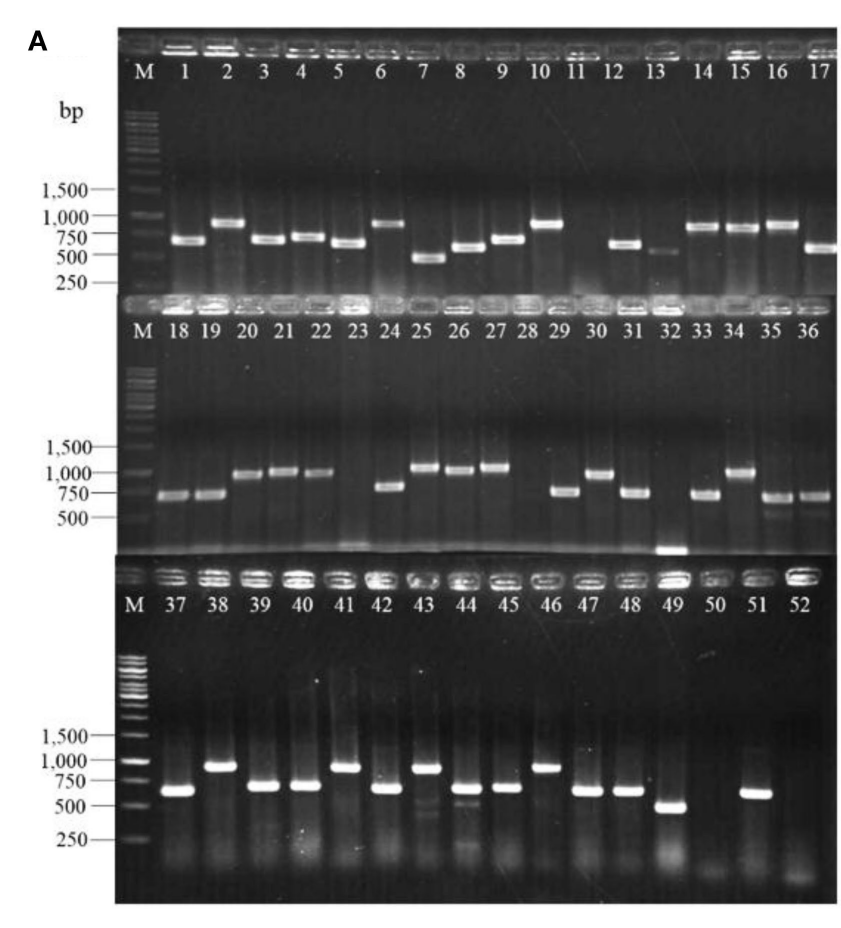

B
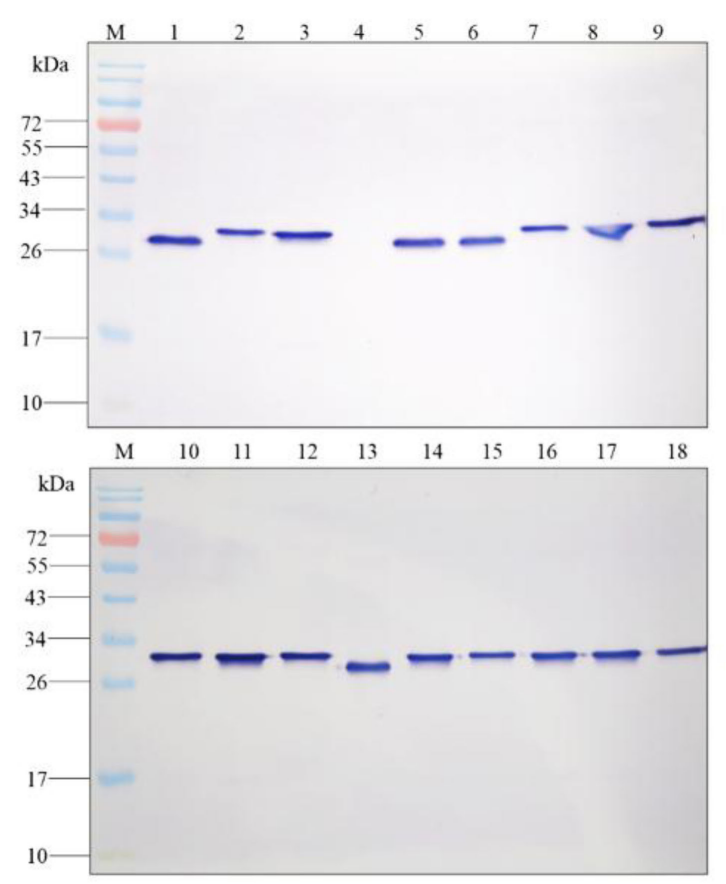

D

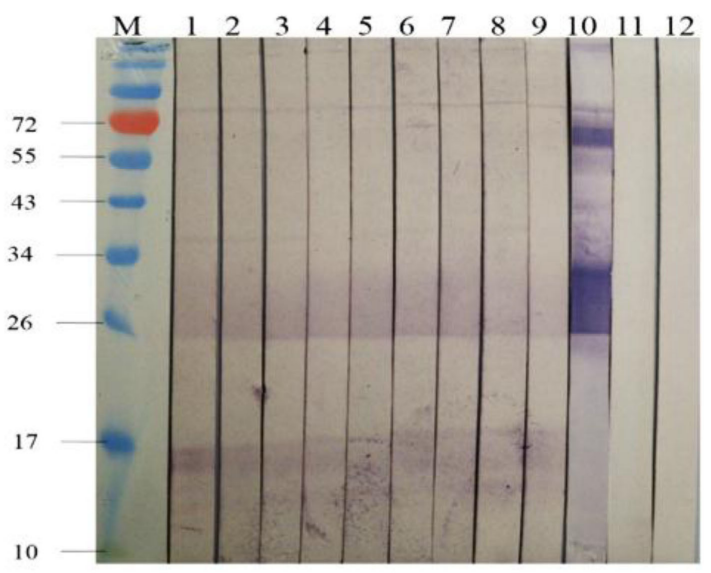

C

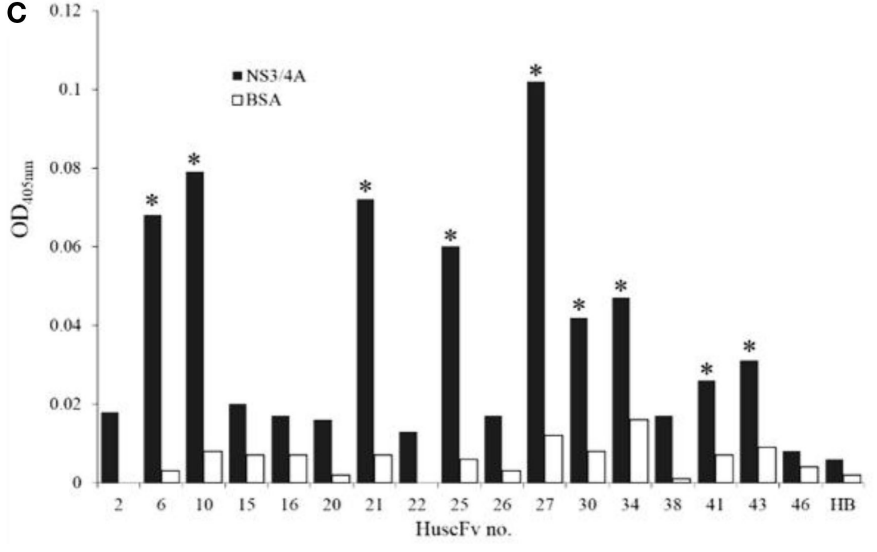

E

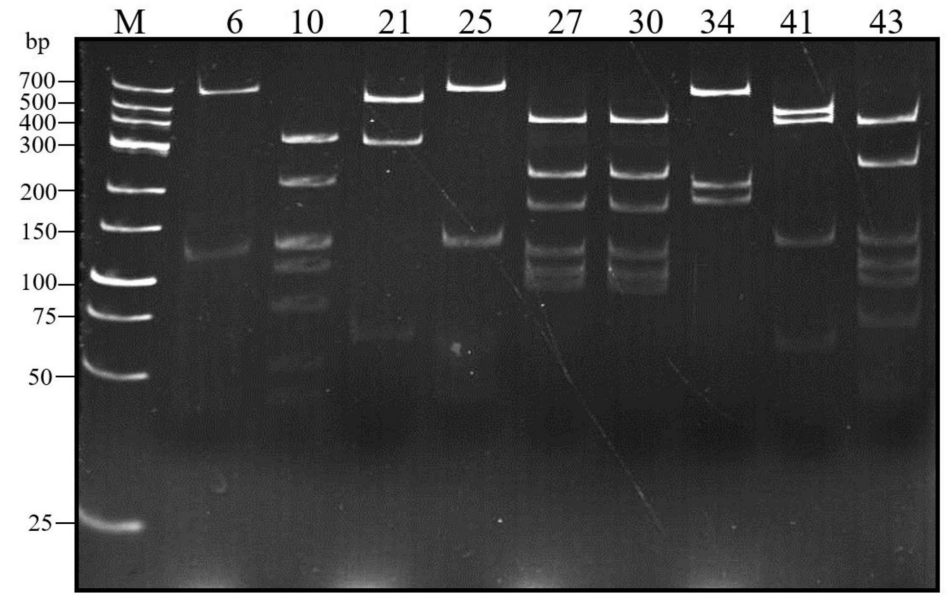




\section{FIGURE 1 | Continued}

Results of PCR for amplification of huscfvs using 52 E. coli bacteria infected with individual phages that bound to recombinant NS3/4A as templates; 18 clones (34.6\%) revealed the huscfvs at about 1,000 base pairs (bp) (A). After growing the huscfv-positive clones under $0.5 \mathrm{mM} \mathrm{IPTG}$ induction, the bacterial lysates were checked for HuscFvs by Western blot analysis. Seventeen of the 18 clones produced the HuscFvs seen as bands at $27-32 \mathrm{kDa}$ (B). After standardizing spectrophotometrically, the HuscFvs were tested for their ability to bind to the NS3/4A by indirect ELISA. The antibodies produced by nine phage-transformed E. coli clones (nos. 6, 10, 21, 25, 27, 30, 34, 41, and 43) gave significant ELISA signal to the rNS3/4A above control antigen (BSA) and negative HuscFv contol (HB or lysate of original HB2151 E. coli) (C). Binding of the HuscFvs from the nine clones was verified by Western blotting. The HuscFvs were used to probe the SDS-PAGE-separated rNS3/4A, and all of them bound to the antigen seen as diffuse bands at 26-32 kDa (lanes 1-9) (D); lane 10, positive binding control which the SDS-PAGE-separated rNS3/4A was probed with mouse anti-NS3/4A polyclonal antibodies. Lanes M of (B) and (D), protein marker; numbers at the left are protein molecular masses in kDa. Restriction fragment length polymorphism (RFLP) of the huscfvs of the clones (E). Lanes M of (A) and (E), DNA marker; numbers at the left are DNA sizes in bp.

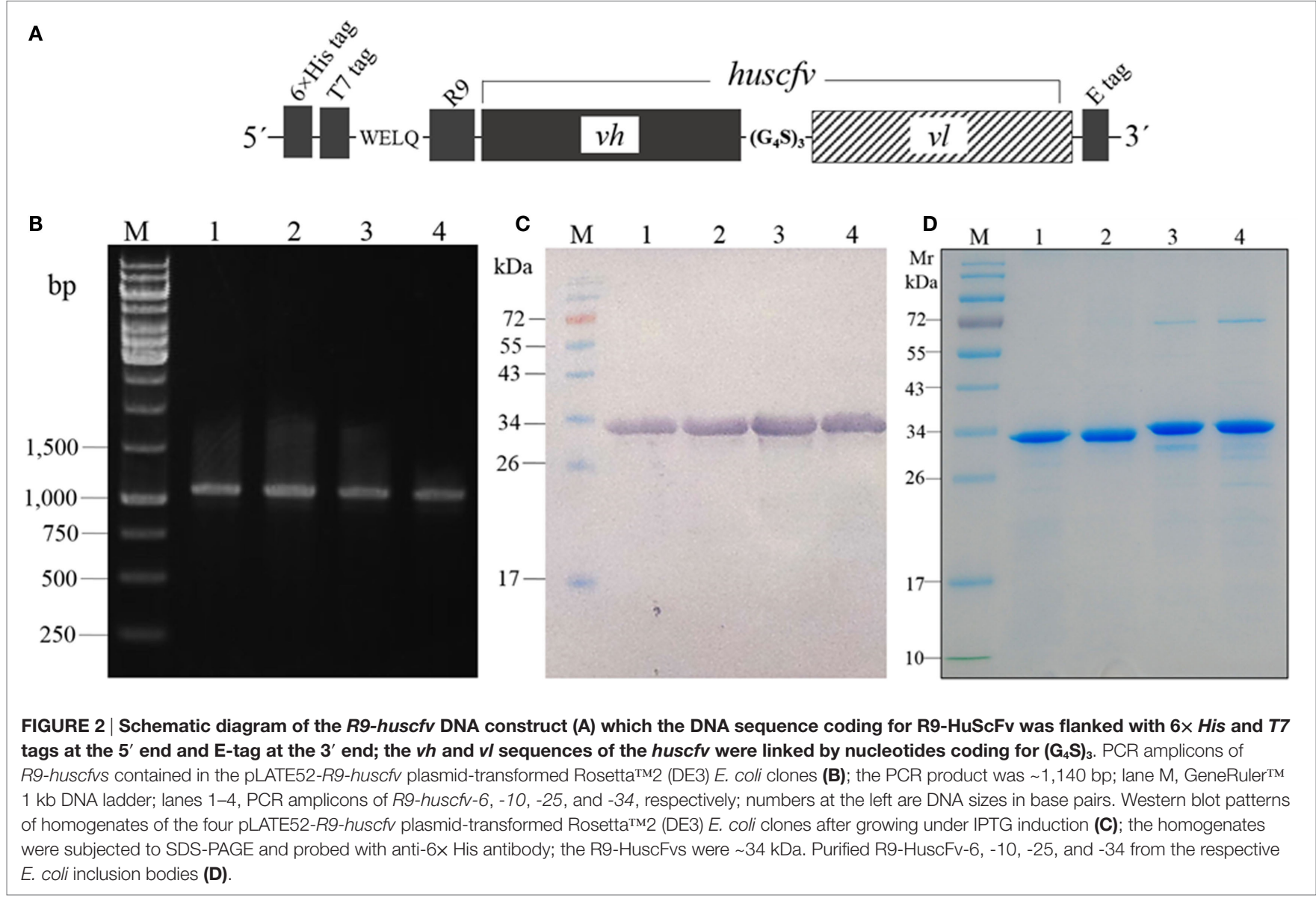

three CDRs of both VH and VL domains with linker nucleotides coding for $\left(\mathrm{G}_{4} \mathrm{~S}\right)_{3}$ in between the domains. Therefore, these clones were selected for further experiments.

\section{Cell Penetrable HuscFvs (transbodies) and Their Cell Penetrating Ability and Toxicity}

The huscfvs of the clones 6,10,25, and 34 in the pCANTAB5Ehuscfv recombinant phagemids were subcloned into the pLATE52 plasmids downstream of the R9 gene, and the recombinant plasmids were put into the Rosetta ${ }^{\mathrm{TM}} 2$ (DE3) E. coli. Figure 2A shows schematic diagram of the R9-HuscFv DNA construct. Examples of the PCR products amplified from the
pLATE52-R9-huscfv-transformed RosettaTM2 (DE3) E. coli sibling clones are shown in Figure 2B. The R9-HuscFvs with $6 \times$ His and T7 tags at the $N$-terminal and E-tag at the $C$-terminal were produced by growing the respective transformed $E$. coli clones under the $1 \mathrm{mM}$ IPTG induction condition. All clones expressed the R9-HuscFv fusion antibodies at $\sim 32-34 \mathrm{kDa}$ (Figure 2C). Figure 2D shows SDS-PAGE-separated R9-HuscFvs after being purified and refolded. The purified transbodies retained the rNS3/4A binding activity in the indirect ELISA (data not shown).

Ability of the R9-HuscFvs to enter the HCV JFH-1 RNAtransfected Huh7 cells and colocalized with the intracellular NS3/4A protein was determined by immunofluorescence assay and confocal microscopy. Representative result is shown in 
Figure 3. The intracellular R9-HuscFvs probed with rabbit anti-6× His tag followed by goat anti-rabbit immunoglobulinAlexa Flour ${ }^{\circledR} 488$ gave green fluorescence, while the intracellular NS3/4A probed with mouse anti-NS3/4A followed by donkey anti-mouse immunoglobulin-Alexa Flour ${ }^{\circledR} 647$ appeared in red. The DAPI-stained nuclei are seen in blue. After merging, the $\mathrm{R} 9-\mathrm{HuscFv}$ and the NS3/4A were found to colocalize (orange).

Huh7 cells exposed to $25 \mu \mathrm{g}$ of the respective R9-HuscFvs for $24 \mathrm{~h}$ did not release different LDH amounts from cells in medium alone (spontaneous release). The percent calculated viability of the transbody-treated cells was not different from the non-antibodytreated cells (Figure 4A). Likewise, percent cell viability after incubating with the R9-HuscFvs assessed using CellTiter-Glo luminescence assay were not different from the cells in culture medium alone (Figure 4B). Results indicate biocompatibility of the R9-HuscFvs with the mammalian cells.

None of the mice that received, individually, four doses of $25 \mu \mathrm{g} / \mathrm{g}$ body weight of R9-HuscFv10 (representative) and buffer intraperitoneally on every alternate day showed any sign of morbidity (fever, hair ruffle, or diarrhea). They had normal activity and appetite and gained some weight (Figure 4C). Values of some parameters of the mouse blood chemistry at day 7 post-last booster are shown in Table S1 in Supplementary Material.

\section{Transbody-mediated Inhibition of the HCV Replication}

The HCV 5' UTR copy numbers recovered from the HCV-RNA-transfected Huh7 cells that had been exposed to the NS3/4A-bound-R9-HuscFv-6, -10, -25, and -34 are shown in Figure 5 in comparison with various controls (positive and negative inhibition controls). Among the R9-HuscFvs, the R9-HuscFv10 and R9-HuscFv6 were the most effective transbodies in reducing the amount of the intracellular HCV RNA. Efficacies of all inhibitors and controls in reducing the intracellular HCV RNA are statistically compared as shown in Table 1.

Amounts of HCV 5' UTR RNA in culture supernatants of all groups of the treated cells are shown in Figure 6. The most effective R9-HuscFvs in reducing the HCV RNA in the transfected cell culture supernatants were R9-HuscFv10 and R9-HuscFv6. Statistical differences of the effectiveness among groups are shown in Table 2.

Results of the assay for determining the HCV foci in transfected cells treated with R9-HuscFvs and controls are shown in Figure 7. Statistical comparison among all treatment groups are shown in Table 3. Figure S1 in Supplementary Material shows appearance of the HCV foci in cells of individual treatment groups after staining with anti-HCV core protein as the primary antibody. The

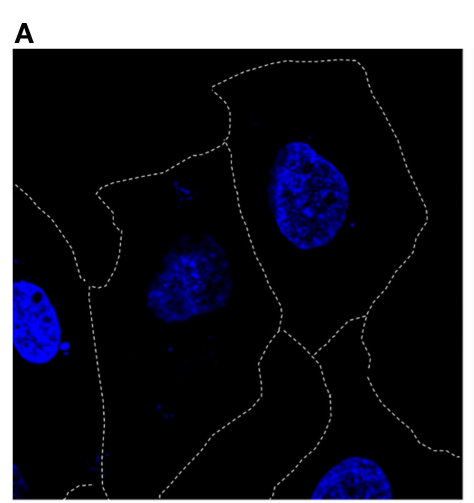

D

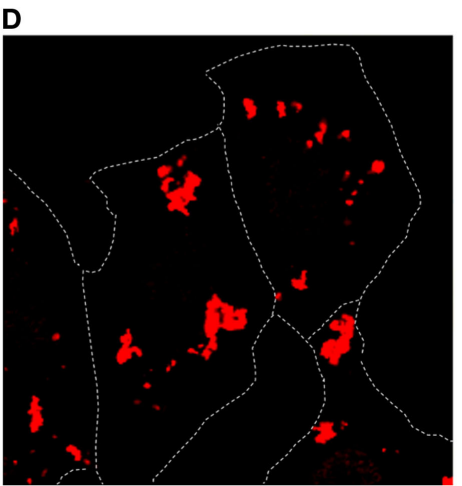

C

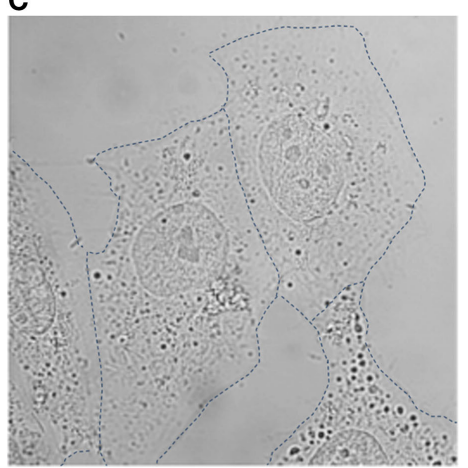

E

FIGURE 3 | Immunofluorescence staining and confocal microscopy for determining entry of R9-HuscFv10 (as representative) into HCV JFH-1 RNA-transfected Huh7 cells and the R9-HuscFv binding to the intracellular NS3/4A. HCV JFH-1 RNA-transfected Huh7 cells were incubated with the R9-HuscFv then stained (see Materials and Methods). Cells stained with DAPI for localization of nuclei (blue) (A). Intracellular R9-HuscFv probed with rabbit anti-6x His tag followed by goat anti-rabbit immunoglobulin-Alexa Flour ${ }^{\circledR 88}$ (Green) (B). Bright field (C). Intracellular NS3/4A probed with mouse anti-NS3/4A followed by donkey anti-mouse immunoglobulin-Alexa Flour ${ }^{\circledR} 647$ (red) (D). Merged A, B, and D (E). The R9-HuscFv readily entered the HCV-infected cells and colocalized with the intracellular NS3/4A (orange). 

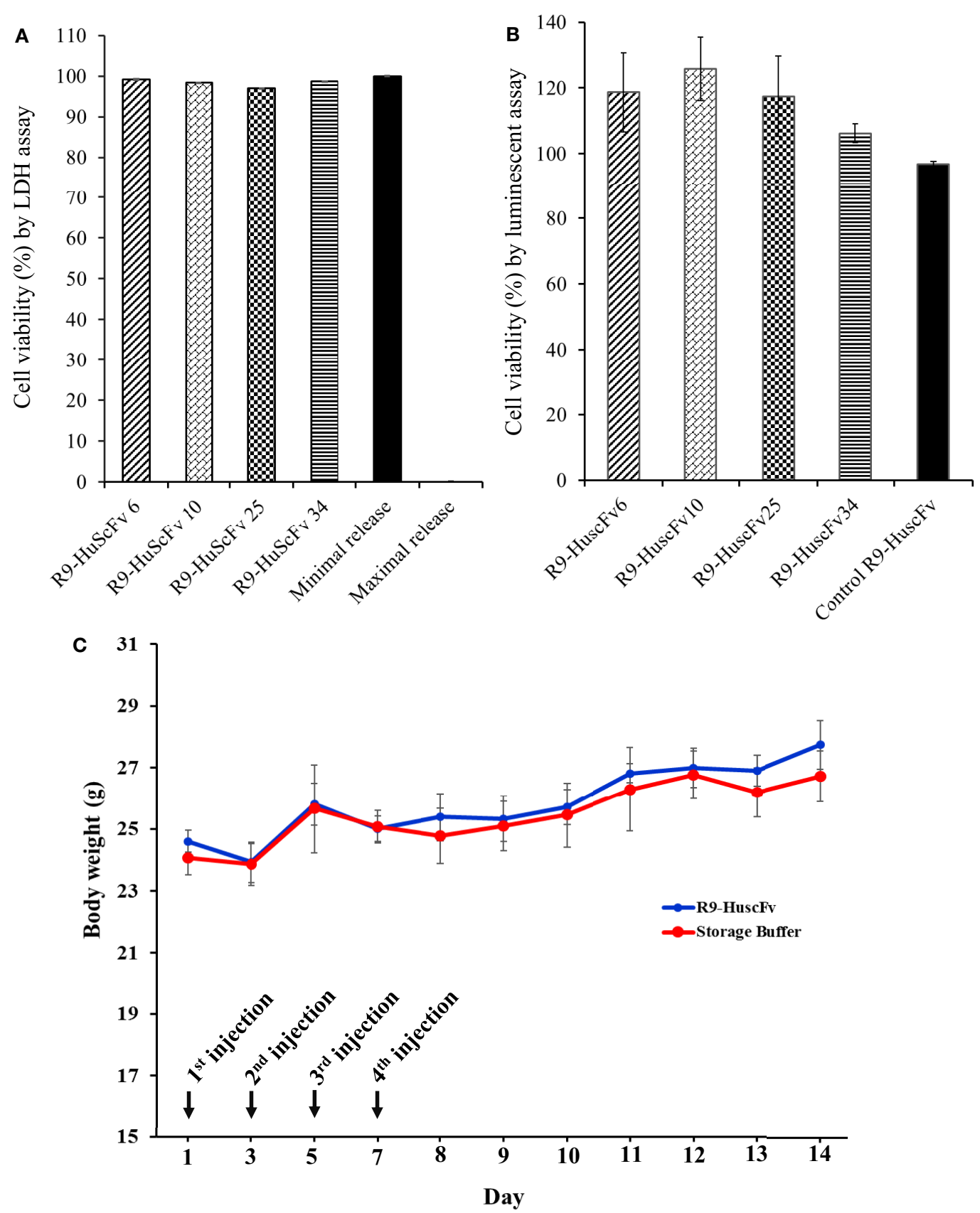

FIGURE 4 | Viability of the Huh7 cells after treating with R9-HuscFvs and controls as determined by LDH assay (A) and CellTiter-Glo ${ }^{\circledR}$ Luminescent assay (B). For (A), Huh7 cells were incubated with $25 \mu \mathrm{g}$ of R9-HuscFv-6, -10, -25, or -34. LDH in the cell culture medium was detected $24 \mathrm{~h}$ after adding the antibodies or controls, i.e., cells in medium alone (minimal/spontaneous LDH release) and cells added with 10\% SDS (maximal LDH release). The calculated percent viability of the transbodies-treated cells was not different from the spontaneous (minimal) release. For (B), Huh7 cells were incubated with $25 \mu \mathrm{g}$ of R9-HuscFvs or medium for $48 \mathrm{~h}$ and percent cell viability were determined using the Cell Titer-Glo ${ }^{\circledR}$ Luminescent Cell Viability Assay kit. The R9-HuscFvs did not cause significant reduction of the cell viability compared with the cells cultured in the medium alone. Daily body weights of mice injected intraperitoneally (C) with $\mathrm{R} 9$-HuscFv10 (as representative; blue line) compared with control mice that were injected with buffer alone (red line); all mice gained some weights during 14 days of experiment and did not show any sign of morbidity. Some biochemical parameters of the mouse blood samples are shown in Table S1 in Supplementary Material.

effectiveness of the transbodies and the controls in reducing the numbers of HCV foci in the transfected cells were conformed to the results of the 5' UTR RNA expression assay determined by the qRT-PCR. The R9-HuscFv10 was highly effective.

\section{Response of the HCV-RNA-transfected} Cells after Treatment with the Transbodies

Details of the fold change of mRNA expressions of the innate immune response genes, including TRIF, TRAF3, IRF3, IL-28B, 


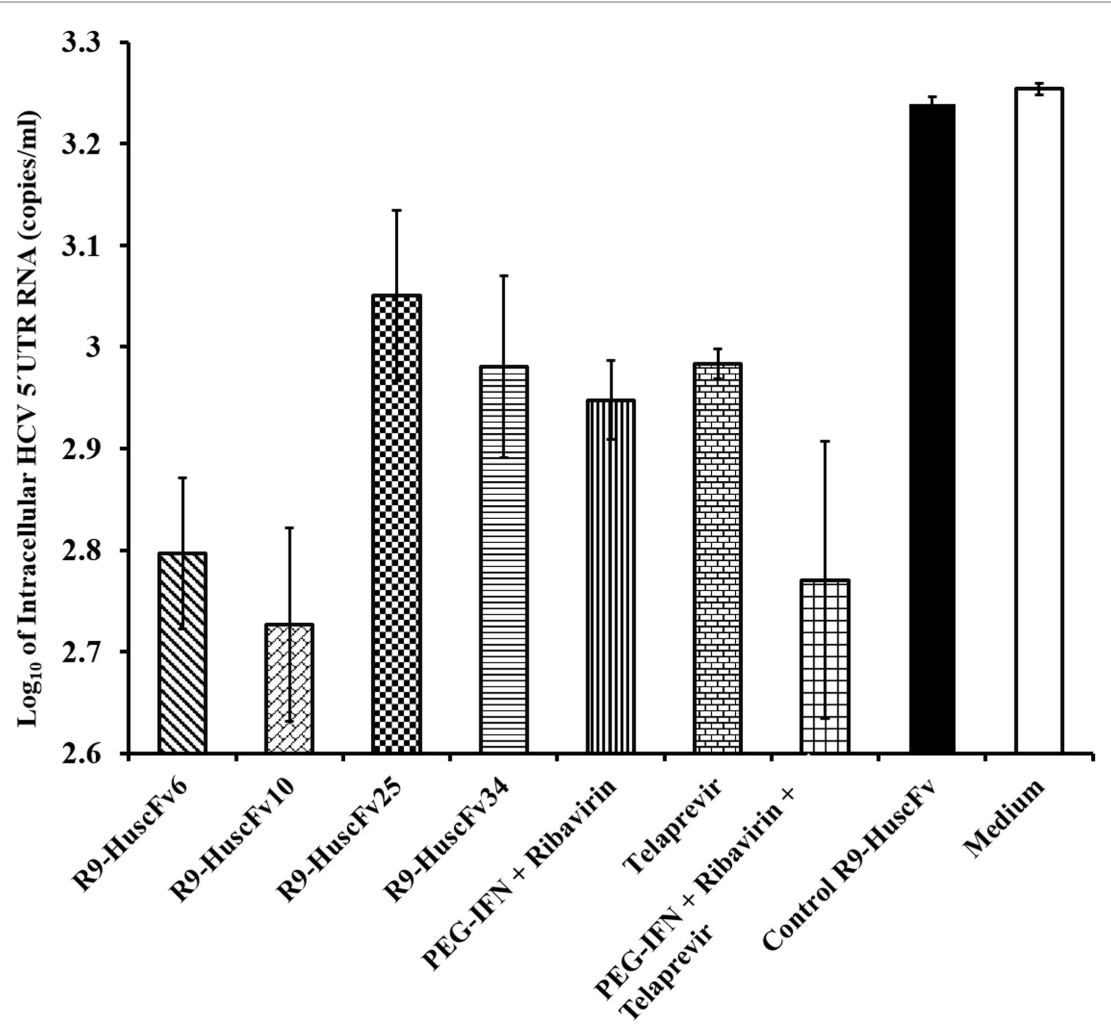

FIGURE 5 | Amounts of HCV 5' UTR RNA in the JFH-1 RNA-transfected Huh7 cells after treating with the R9-HuscFv-6, -10, -25, and -34 in comparison with controls. Table 1 shows $p$ values for statistical comparison among different treatments.

TABLE 1 | Statistical comparison of the results of the HCV 5' UTR mRNA copy numbers recovered from the HCV-RNA-transfected Huh7 cells that had been exposed to the NS3/4A-bound R9-HuscFvs and various controls.

\begin{tabular}{|c|c|c|c|c|c|c|c|c|c|}
\hline \multirow[t]{2}{*}{ Treatment } & \multicolumn{5}{|c|}{ HuscFv } & \multicolumn{3}{|c|}{ Positive inhibition control } & \multirow[t]{2}{*}{ Medium } \\
\hline & 6 & 10 & 25 & 34 & Control & $\begin{array}{c}\text { PEG- } \\
\text { IFN + ribavirin }\end{array}$ & Telaprevir & $\begin{array}{c}\text { PEG-IFN + ribavirin + } \\
\text { telaprevir }\end{array}$ & \\
\hline \multicolumn{10}{|l|}{ HuscFv } \\
\hline 6 & NS & $p=0.21$ & $p<0.05$ & $p<0.05$ & $p<0.05$ & $p<0.05$ & $p<0.05$ & $p=0.43$ & $p<0.05$ \\
\hline 10 & $p=0.21$ & NS & $p<0.05$ & $p<0.05$ & $p<0.05$ & $p<0.05$ & $p<0.05$ & $p=0.64$ & $p<0.05$ \\
\hline 25 & $p<0.05$ & $p<0.05$ & NS & $p=0.39$ & $p<0.05$ & $p<0.05$ & $p=0.34$ & $p<0.05$ & $p<0.05$ \\
\hline 34 & $p<0.05$ & $p<0.05$ & $p=0.39$ & NS & $P<0.05$ & $p=0.23$ & $p=0.93$ & $p<0.05$ & $p<0.05$ \\
\hline Control & $p<0.05$ & $p<0.05$ & $p<0.05$ & $p<0.05$ & NS & $p<0.05$ & $p<0.05$ & $p<0.05$ & $p=0.77$ \\
\hline \multicolumn{10}{|l|}{ Positive inhibition control } \\
\hline PEG-IFN + ribavirin & $p<0.05$ & $p<0.05$ & $p<0.05$ & $p=0.23$ & $P<0.05$ & NS & $p=0.27$ & $p<0.05$ & $p<0.05$ \\
\hline Telaprevir & $p<0.05$ & $p<0.05$ & $p=0.34$ & $p=0.93$ & $p<0.05$ & $p=0.27$ & NS & $p<0.05$ & $p<0.05$ \\
\hline PEG-IFN + ribavirin + telaprevir & $p=0.43$ & $p=0.64$ & $p<0.05$ & $p<0.05$ & $p<0.05$ & $p<0.05$ & $p<0.05$ & NS & $p<0.05$ \\
\hline Medium & $p<0.05$ & $p<0.05$ & $p<0.05$ & $p<0.05$ & $p=0.77$ & $p<0.05$ & $p<0.05$ & $p<0.05$ & NS \\
\hline
\end{tabular}

NS, not significantly different.

and IFN- $\beta$, after various treatments in comparison with the non-transfected (normal) Huh7 cells cultured in the medium are shown in Table 4. The R9-HuscFv6 and R9-HuscFv10 restored expressions of all studied host innate immune response genes. The control transbody-exposed transfected cells and the transfected cells maintained in medium alone had lower expressions of the genes than the non-transfected (normal) cells. At the condition and time of the experiments, TRAF3 and $I L-28 \beta$ mRNAs could not be rescued by the R9-HuscFv25 and R9-HuscFv34, respectively. All positive inhibitors, particularly the combined PEG-IFN- $\alpha$ + ribavirin + telaprevir effectively restored expressions of all of the studied genes. 


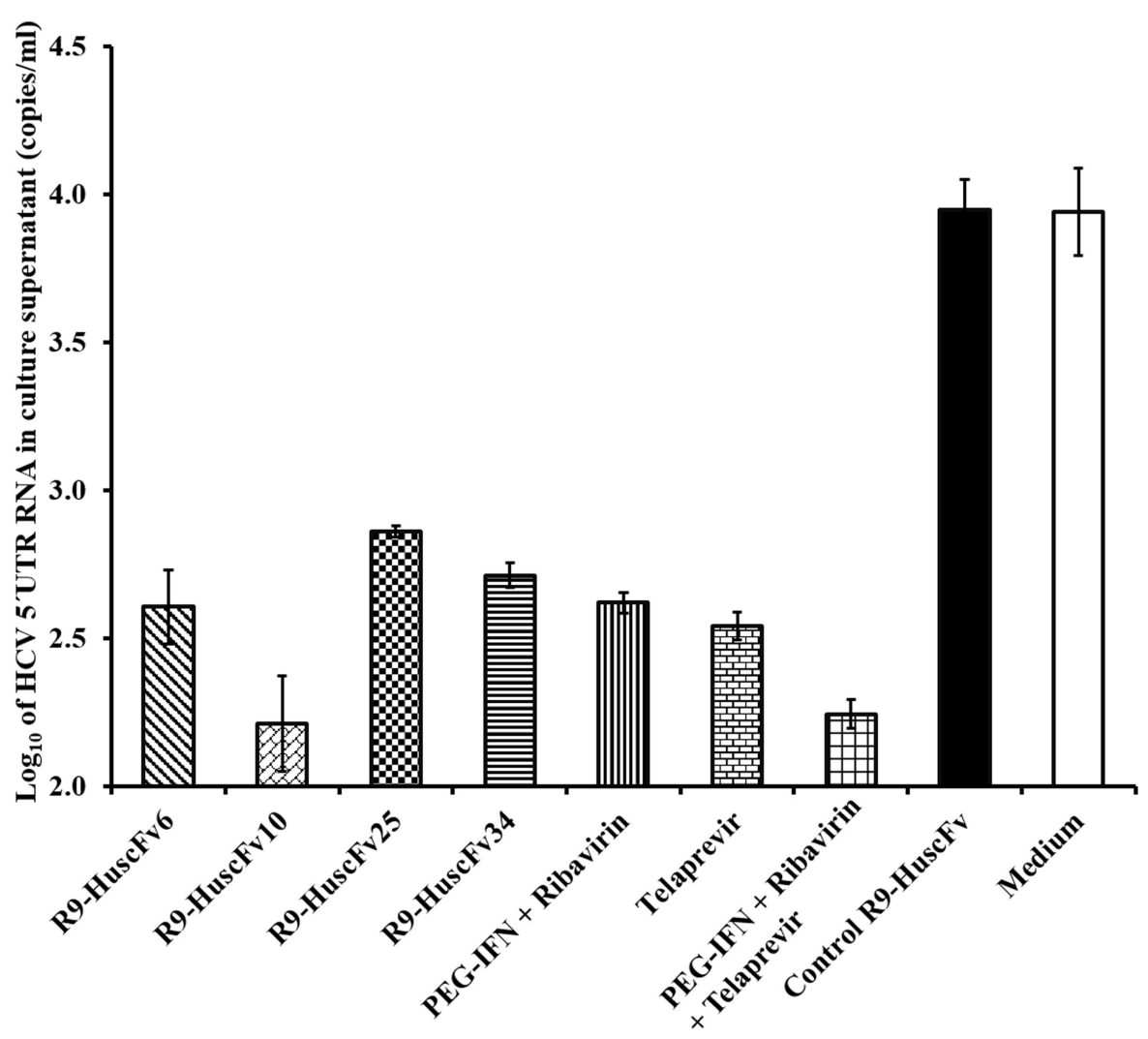

FIGURE 6 | Amounts of HCV 5' UTR RNA in culture fluids after treating with the R9-HuscFv-6, -10, -25 and -34 in comparison with controls. Table 2 shows $p$ values for statistical comparison among different treatments.

TABLE 2 | Statistical comparison of the results of the HCV 5' UTR copy numbers recovered from culture supernatants of the HCV-RNA-transfected Huh7 cells that had been treated with R9-HuscFv-6, -10, -25, and -34 and various controls.

\begin{tabular}{|c|c|c|c|c|c|c|c|c|c|}
\hline \multirow[t]{2}{*}{ Treatment } & \multicolumn{5}{|c|}{ HuscFv } & \multicolumn{3}{|c|}{ Positive inhibition control } & \multirow[t]{2}{*}{ Medium } \\
\hline & 6 & 10 & 25 & 34 & Control & $\begin{array}{c}\text { PEG- } \\
\text { IFN + ribavirin }\end{array}$ & Telaprevir & $\begin{array}{c}\text { PEG-IFN + ribavirin + } \\
\text { telaprevir }\end{array}$ & \\
\hline \multicolumn{10}{|l|}{ HuscFv } \\
\hline 6 & NS & $p<0.05$ & $p<0.05$ & $p=0.23$ & $p<0.05$ & $p=0.88$ & $p=0.47$ & $p<0.05$ & $p<0.05$ \\
\hline 10 & $p<0.05$ & NS & $p<0.05$ & $p<0.05$ & $p<0.05$ & $p<0.05$ & $p<0.05$ & $p=0.71$ & $p<0.05$ \\
\hline 25 & $p<0.05$ & $p<0.05$ & NS & $p<0.05$ & $p<0.05$ & $p=0.24$ & $p=0.05$ & $p<0.05$ & $p<0.05$ \\
\hline 34 & $p=0.23$ & $p<0.05$ & $p<0.05$ & NS & $P<0.05$ & $p=0.29$ & $p=0.17$ & $p<0.05$ & $p<0.05$ \\
\hline Control & $p<0.05$ & $p<0.05$ & $p<0.05$ & $p<0.05$ & NS & $p<0.05$ & $p<0.05$ & $p<0.05$ & $p=0.94$ \\
\hline \multicolumn{10}{|c|}{ Positive inhibition control } \\
\hline PEG-IFN + ribavirin & $p=0.88$ & $p<0.05$ & $p<0.05$ & $p=0.29$ & $P<0.05$ & NS & $p=0.39$ & $p<0.05$ & $p<0.05$ \\
\hline Telaprevir & $p=0.47$ & $p<0.05$ & $p<0.05$ & $p<0.05$ & $p<0.05$ & $p=0.39$ & NS & $p<0.05$ & $p<0.05$ \\
\hline $\begin{array}{l}\text { PEG- } \\
\text { IFN + ribavirin + telar }\end{array}$ & $p<0.05$ & $p=0.71$ & $p<0.05$ & $p<0.05$ & $p<0.05$ & $p<0.05$ & $p<0.05$ & NS & $p<0.05$ \\
\hline Medium & $p<0.05$ & $p<0.05$ & $p<0.05$ & $p<0.05$ & $p=0.94$ & $p<0.05$ & $p<0.05$ & $p<0.05$ & NS \\
\hline
\end{tabular}

NS, not significantly different.

\section{Homology Modeling and Intermolecular Docking for Predicting the Presumptive Residues of the HCV NS3/4A Interacted with the HuscFvs}

The top 10 treading templates used to model the HuscFv6, HuscFv10, HuscFv25, and HuscFv34 by I-TASSER and the top 10 identified structural analogs of the HuscFvs in the PDB are shown in Tables S2A,B-S5A,B in Supplementary Material, respectively. Table S6 in Supplementary Material gives details of the qualities of the I-TASSER-predicted HuscFv models used in this study. The ClusPro lowest local energies of interactions between the NS3/4A 3D structure and the modeled HuscFv6, HuscFv10, HuscFv25, and HuscFv34 were $-356,-428,-290$, and $-293 \mathrm{kcal} / \mathrm{mol}$, 


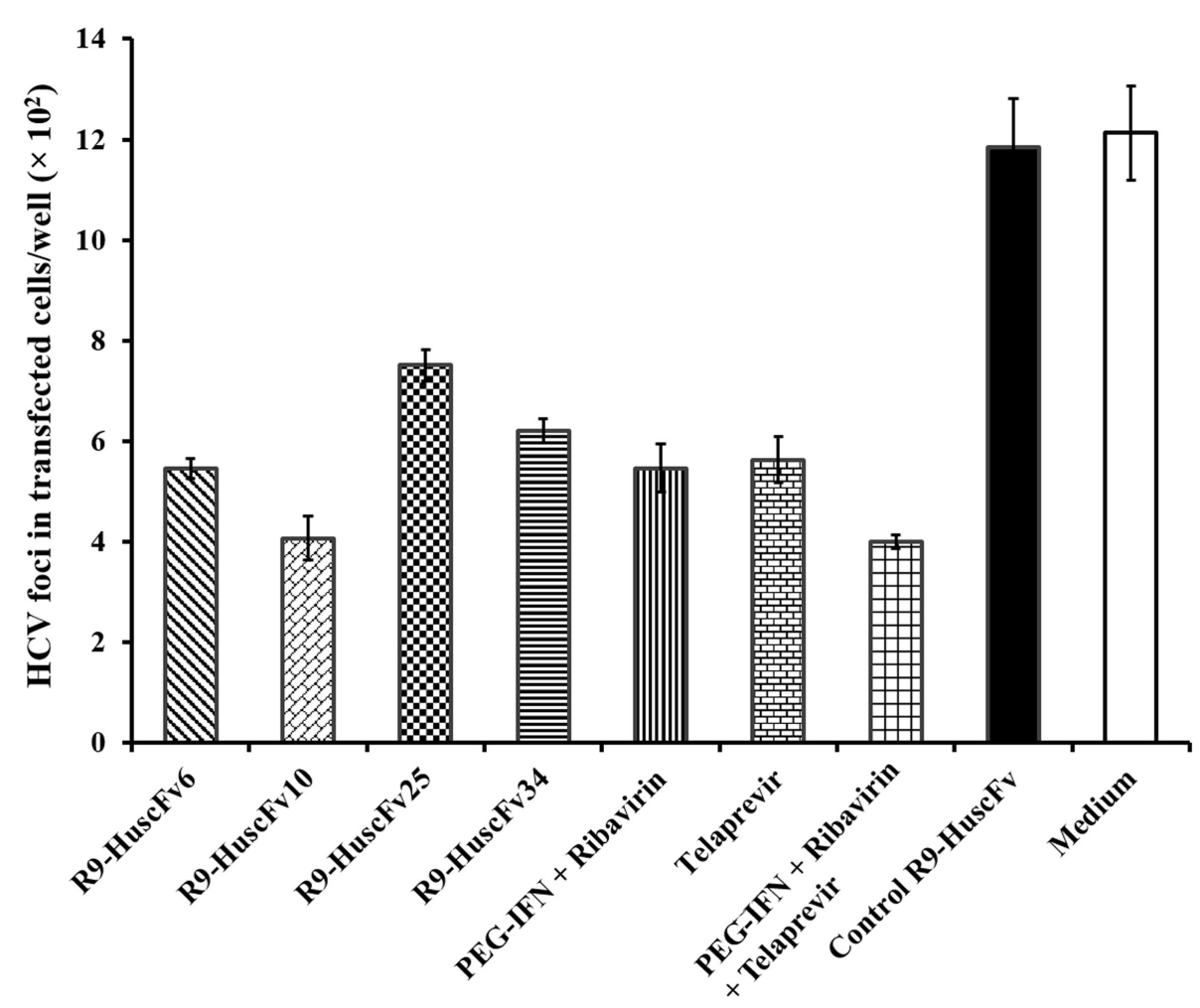

FIGURE 7 | Foci of HCV in the HCV-RNA-transfected Huh7 cells after exposure to the R9-HuscFv-6, -10, -25, and -34 in comparison with controls Table 3 shows $p$ values for statistical comparison among different treatments.

TABLE 3 | Statistical comparison of the results of the HCV foci assay among HCV-RNA-transfected Huh7 cells treated with R9-HuscFvs and various controls.

\begin{tabular}{|c|c|c|c|c|c|c|c|c|c|}
\hline \multirow[t]{2}{*}{ Treatment } & \multicolumn{5}{|c|}{ HuscFv } & \multicolumn{3}{|c|}{ Positive inhibition control } & \multirow[t]{2}{*}{ Medium } \\
\hline & 6 & 10 & 25 & 34 & Control & $\begin{array}{c}\text { PEG- } \\
\text { IFN + ribavirin }\end{array}$ & Telaprevir & $\begin{array}{c}\text { PEG-IFN + ribavirin + } \\
\text { telaprevir }\end{array}$ & \\
\hline \multicolumn{10}{|l|}{ HuscFv } \\
\hline 6 & NS & $p<0.05$ & $p<0.05$ & $p=0.20$ & $p<0.05$ & $p=0.99$ & $p=0.75$ & $p<0.05$ & $p<0.05$ \\
\hline 10 & $p<0.05$ & NS & $p<0.05$ & $p<0.05$ & $p<0.05$ & $p<0.05$ & $p<0.05$ & $p=0.90$ & $p<0.05$ \\
\hline 25 & $p<0.05$ & $p<0.05$ & NS & $p<0.05$ & $p<0.05$ & $p<0.05$ & $p<0.05$ & $p<0.05$ & $p<0.05$ \\
\hline 34 & $p=0.20$ & $p<0.05$ & $p<0.05$ & NS & $P<0.05$ & $p=0.20$ & $p=0.31$ & $p<0.05$ & $p<0.05$ \\
\hline Control & $p<0.05$ & $p<0.05$ & $p<0.05$ & $p<0.05$ & NS & $p<0.05$ & $p<0.05$ & $p<0.05$ & $p=0.61$ \\
\hline \multicolumn{10}{|l|}{ Positive inhibition control } \\
\hline PEG-IFN + ribavirin & $p=0.99$ & $p<0.05$ & $p<0.05$ & $p=0.20$ & $P<0.05$ & NS & $p=0.77$ & $p<0.05$ & $p<0.05$ \\
\hline Telaprevir & $p=0.75$ & $p<0.05$ & $p<0.05$ & $p=0.31$ & $p<0.05$ & $p=0.77$ & NS & $p<0.05$ & $p<0.05$ \\
\hline $\begin{array}{l}\text { PEG- } \\
\text { IFN + ribavirin + telaprevir }\end{array}$ & $p<0.05$ & $p=0.90$ & $p<0.05$ & $p<0.05$ & $p<0.05$ & $p<0.05$ & $p<0.05$ & NS & $p<0.05$ \\
\hline Medium & $p<0.05$ & $p<0.05$ & $p<0.05$ & $p<0.05$ & $p=0.61$ & $p<0.05$ & $p<0.05$ & $p<0.05$ & NS \\
\hline
\end{tabular}

NS, not significantly different.

respectively. Details of intermolecular docking, including the interactive residues of the NS3/4A/HCV polyprotein and motives and amino acids and domains of the HuscFvs as well as the interactive bonds between the two parties, are shown in Table 5 and Figures S2-S5 in Supplementary Material. Besides the molecular bonds in Table 5, the amino acid residues of the NS3/4A within $5 \AA$ thresholds of van der Waals radii of HuscFvs are shown separately in Table 6.
The most effective HuscFv10 in inhibiting the HCV replication was found to form interface contact with many critical residues of the NS3/4A important for protease activity including H57 and D81 of the catalytic triad, Y56 and D79 near to the catalytic site, K136 and G137 of the oxyanion loop, and K20 of NS4A cofactor which is adjacent to the NS4A residues $21-34$ that usually interacts with the NS3 for enhancing the protease activity (Table 5B and Figure S2 in Supplementary Material). Table 6B shows the 
TABLE 4 | Fold change of innate immune response genes in HCV-RNA-transfected human hepatic cells compared to non-transfected cells after treating with NS3/4A specific-R9-HuscFvs and various controls.

\begin{tabular}{|c|c|c|c|c|c|c|c|c|c|}
\hline \multirow[t]{3}{*}{ Gene } & \multicolumn{9}{|c|}{ Fold change of mRNAs of innate immune response genes in HCV-RNA-transfected cells treated with } \\
\hline & \multicolumn{4}{|c|}{ R9-HuscFv } & \multirow{2}{*}{$\begin{array}{c}\text { PEG-IFN } \alpha- \\
2 a+\text { ribavirin }\end{array}$} & \multirow[t]{2}{*}{ Telaprevir } & \multirow{2}{*}{$\begin{array}{c}\text { PEG-IFNo- } \\
2 \mathrm{a}+\text { ribavirin + telaprevir }\end{array}$} & \multirow{2}{*}{$\begin{array}{c}\text { Control } \\
\text { R9-HuScFv }\end{array}$} & \multirow[t]{2}{*}{ Medium } \\
\hline & 6 & 10 & 25 & 34 & & & & & \\
\hline TRIF & $45.89 \uparrow$ & $49.52 \uparrow$ & $3.23 \uparrow$ & $1.25 \uparrow$ & $28.64 \uparrow$ & $10.78 \uparrow$ & $150.12 \uparrow$ & $1.18 \downarrow$ & $1.08 \downarrow$ \\
\hline TRAF3 & $32.67 \uparrow$ & $83.87 \uparrow$ & $1.75 \downarrow$ & $1.97 \uparrow$ & $15.14 \uparrow$ & $11.96 \uparrow$ & $64.89 \uparrow$ & $1.23 \downarrow$ & $1.82 \downarrow$ \\
\hline IRF3 & $22.78 \uparrow$ & $32.90 \uparrow$ & $3.71 \uparrow$ & $3.05 \uparrow$ & $8.69 \uparrow$ & $11.96 \uparrow$ & $26.09 \uparrow$ & $5.55 \downarrow$ & $1.11 \downarrow$ \\
\hline IL-28B & $15.67 \uparrow$ & $10.41 \uparrow$ & $1.89 \uparrow$ & $3.57 \downarrow$ & $22.16 \uparrow$ & $6.11 \uparrow$ & $34.06 \uparrow$ & $3.70 \downarrow$ & $2.00 \downarrow$ \\
\hline IFN $\beta 1$ & $16.45 \uparrow$ & $51.98 \uparrow$ & $6.36 \uparrow$ & $4.66 \uparrow$ & $53.08 \uparrow$ & $18.90 \uparrow$ & $125.37 \uparrow$ & $1.64 \downarrow$ & $1.32 \downarrow$ \\
\hline
\end{tabular}

$\uparrow$, fold increase; $\downarrow$, fold decrease.

van de Waals forces that may contribute also to the HuscFv10target association.

The HuscFv6, which was also highly effective in HCV replication inhibition, did not interact with any residues of the catalytic triad (H57, D81, and S139), oxyanion loop (135LKGSS139), or residues C97, C99, C145, and H149 of the zinc binding site. Instead, center of target binding of this HuscFv6 was located at the basic triad, i.e., 117RRR119, and R123 of the NS3/4A $\beta-\mathrm{B} 2$ and $\beta$-C2 motives (Tables 5A and 6A and Figure S3 in Supplementary Material).

The HuscFv25, similar to the HuscFv6, interacted with the basic residues: R117, R119, and R123, although at the higher local energy than the HuscFv6 (Tables 5C and 6C and Figure S4 in Supplementary Material).

The HuscFv34 not only interacted with the 117RRR119 but also with the P146 and T/S147 in the zinc binding site of the protease (Tables 5D and 6D and Figure S5 in Supplementary Material).

\section{DISCUSSION}

There is a need of an improved regimen/remedy for treatment of HCV infection. A novel DAA that we would like to offer for future development is the engineered cell-penetrating human/ humanized small antibody fragments that interfere with enzymes of the virus. The NS3/4A serine protease is pivotal for releasing mature NS4A, NS4B, NS5A, and NS5B from polyprotein (42) for the $\mathrm{HCV}$ replication, assembly, and egress. It also suppresses the host innate antiviral response.

During the early phase of infection, molecular signatures of intracellular viruses usually alarm the host pathogen recognition receptors (PRRs), including endosomal Toll-like receptors (TLRs), and cytosolic retinoic acid-inducible gene 1/helicard (RIG-1/Mda5) to activate various adaptor proteins, i.e., TRIF (Toll-IL-1 receptor domain-containing adaptor inducing IFN- $\beta$ ), Cardif/MAVS, and TRAFs (tumor necrosis factor-associated factors). These factors consequently activate kinases (TBK1 and IKKs) leading to phosphorylation and dimerization of interferon regulatory factor 3/7 (IRF3/7) transcription factor for production of innate interferons, including type-I IFN- $\beta$ and type-III IFN- $\lambda$ (IL-28/29) (43-45). The IFNs mediate autocrine and paracrine stimulation of the host cells through JAK/STAT signaling pathways leading to production of various antiviral factors, i.e., $2^{\prime}$, 5' OAS, PKR, MxA, and ISGs, as well as MHC class I molecules for cytotoxic lymphocyte activation (45). NS3/4A protein of the infecting HCV cleaves TRIF and Cardif/MAVS, binds to TBK1, and inhibits activation of IRF3 (46-48). Moreover, the protein has been implicated in malignant transformation (49-51). The NS3 N-terminal is known to interact with p53 (a tumor suppressor) and inhibited apoptosis of NIH3T3 cells $(51,52)$. As such, interference with the HCV NS3/4A functions should lead to inhibition of the viral replication as well as restoration of the virally suppressed host innate immune response and might as well reduce the hepatocellular carcinoma incidence among the chronically infected subjects.

In this study, bacterially derived engineered human single chain antibodies that bound to active $\mathrm{HCV} \mathrm{NS3/4A} \mathrm{protein} \mathrm{were}$ generated. Because the antibody target is located intracellularly, the antibodies were made into cell penetrable molecules by linking their coding sequences to nonaarginine (R9) nucleotides using a ligase-independent cloning (LIC) method. The R9-HuscFvs were readily purified from the IBs of four E. coli clones (nos. 6, 10,25 , and 34) carrying the R9-huscfv plasmids and successfully refolded using the protocol adapted from (53) and instruction manual of the Protein Refolding Kit of Novagen. The R9-HuscFvs retained their binding to the rNS3/4A as the parental HuscFvs (data not shown) indicating the native refolding of the antibodies. They readily entered the human hepatic cells (Huh7) and bound to the intracellular target. They did not cause significant LDH leakage from the cocultured human hepatic cells compared with the cells in the medium alone indicating compatibility of the antibody preparations with the mammalian cells at the dose that was tested. Safety of the transbodies was also demonstrated in mice after injecting them intraperitoneally (followed the Thai Pharmacopia) at the dose that was relatively high $(25 \mu \mathrm{g} / \mathrm{g}$ body weight) for passive immunization in humans (37).

There were significant reductions of the HCV 5'UTR RNA in the Huh7 cells transfected with JFH-RNA and in the cell culture supernatants after treating with the R9-HuscFvs (albeit different degrees of effectiveness among the transbodies from different $E$. coli clones). The results of foci assay were conformed to the RNA quantification. The most effective transbodies were R9-HuscFv10 and R9-HuscFv6. These transbodies could readily restore expressions of all of the studied innate immune response genes of the HCV-RNA-transfected cells. Taken all together, the results indicate that the transbodies-mediated viral replication inhibition and host innate immune response restoration via the NS3/4A protease interference. 
TABLE 5 | Presumptive residues and regions of the NS3/4A and polyprotein of HCV bound by specific HuscFvs.

\begin{tabular}{|c|c|c|c|c|c|}
\hline \multicolumn{3}{|r|}{ HCV protein } & \multicolumn{2}{|c|}{ HuscFv } & \multirow[t]{2}{*}{ Intermolecular bond } \\
\hline NS3 residue & Polyprotein residue & Motif (-ves) & Amino acid & Domain & \\
\hline \multicolumn{6}{|l|}{ A. HuscFv6 } \\
\hline \multirow[t]{2}{*}{$\mathrm{R} 117$} & R1149 & $\beta-\mathrm{B} 2$ & F52 & VH-CDR2 & Cation- $\pi$ \\
\hline & & & Y102 & $\mathrm{VH}-\mathrm{CDR} 3$ & H-bond \\
\hline R118 & $\mathrm{R} 1150$ & $\beta-\mathrm{B} 2$ & Y102 & VH-CDR3 & $\mathrm{CH}-\pi$ \\
\hline \multirow[t]{2}{*}{$\mathrm{R} 119$} & $\mathrm{R} 1151$ & Between $\beta$-B2 and $\beta$-C2 & D33 & VH-CDR1 & Salt-bridge \\
\hline & & & S57 & VH-CDR2 & $\mathrm{H}$-bond \\
\hline D121 & D1153 & Between $\beta$-B2 and $\beta$-C2 & Y166 & VL-CDR1 & H-bond \\
\hline \multirow[t]{2}{*}{ S122 } & S1154 & Between $\beta$-B2 and $\beta-\mathrm{C} 2$ & S227 & VL-CDR3 & H-bond \\
\hline & & & F228 & VL-CDR3 & H-bond \\
\hline \multirow[t]{3}{*}{$\mathrm{R} 123$} & R1155 & Between $\beta$-B2 and $\beta$-C2 & E59 & VH-CDR2 & H-bond \\
\hline & & & E62 & VH-CDR2 & Salt-bridge \\
\hline & & & F228 & VH-CDR3 & $\mathrm{NH}-\pi$ \\
\hline \multirow[t]{2}{*}{ K165 } & K1197 & $\beta-\mathrm{F} 2$ & E55 & VH-CDR2 & Salt-bridge \\
\hline & & & S57 & VH-CDR2 & $\mathrm{H}$-bond \\
\hline P171 & P1203 & $\beta-\mathrm{F} 2$ & Y226 & $\mathrm{VH}-\mathrm{CDR} 3$ & $\mathrm{CH}-\pi$ \\
\hline E173 & E1205 & $\alpha$-helix c & Y226 & VL-CDR3 & H-bond \\
\hline \multicolumn{6}{|l|}{ B. HuscFv10 } \\
\hline T40 & T1071 & Between $\beta$-B1 and $\beta-\mathrm{C} 1$ & E55 & VH-CDR2 & H-bond \\
\hline Y56 & Y1088 & $\alpha$-helix a & Y227 & LCDR3 & $\pi-\pi$ stacking \\
\hline $\mathrm{H} 57$ & H1089 & $\alpha$-helix a (catalytic triad) & Y165 & LCDR1 & $\mathrm{H}$-bond \\
\hline \multirow[t]{3}{*}{ D79 } & D1111 & Between $\beta-\mathrm{E} 1$ and $\beta-\mathrm{F} 1$ & S162 & LCDR1 & Water bridge \\
\hline & & & $\mathrm{R} 164$ & LCDR1 & H-bond \\
\hline & & & S225 & LCDR3 & H-bond \\
\hline D81 & D1113 & Between $\beta$-E1 and $\beta$-F1 (catalytic triad) & Y165 & LCDR1 & H-bond \\
\hline \multirow[t]{2}{*}{ K136 } & K1168 & Between $\alpha$-helix b and $\beta$-D2 (oxyanion loop) & S31 & VH-CDR3 & H-bond \\
\hline & & & Y101 & $\mathrm{VH}-\mathrm{CDR} 3$ & Cation- $\pi$ \\
\hline G137 & G1169 & Between $\alpha$-helix b and $\beta$-D2 (oxyanion loop) & Y102 & VL-CDR1 & H-bond \\
\hline \multirow[t]{2}{*}{$\mathrm{R} 155$} & $\mathrm{R} 1187$ & $\beta-E 2$ & Y165 & $\mathrm{VH}-\mathrm{CDR}$ & H-bond \\
\hline & & & D183 & VL-CDR2 & Salt-bridge \\
\hline A157 & A1189 & $\beta$-E2 & Y105 & $\mathrm{VH}-\mathrm{CDR} 3$ & H-bond \\
\hline \multirow[t]{2}{*}{ NS4A K20 } & K1677 & Close to the first residue of NS4A cofactor peptide that & T58 & VH-CDR2 & $\mathrm{H}$-bond \\
\hline & & binds to NS3 for enhancing the protease activity & E59 & VH-CDR2 & Salt-bridge \\
\hline \multicolumn{6}{|l|}{ C. HuscFv25 } \\
\hline D103 & D1135 & $\beta-A 2$ & R31 & VH-CDR1 & Salt-bridge \\
\hline $\mathrm{R} 117$ & $\mathrm{R} 1149$ & $\beta-\mathrm{B} 2$ & F101 & $\mathrm{VH}-\mathrm{CDR} 3$ & $\mathrm{NH}-\pi$ \\
\hline $\mathrm{R} 119$ & $\mathrm{R} 1151$ & Between $\beta$-B2 and $\beta-\mathrm{C} 2$ & $\mathrm{R} 50$ & VH-CDR2 & Water bridge \\
\hline & & & E99 & VH-CDR3 & Salt-bridge \\
\hline & & & F101 & VH-CDR3 & $\mathrm{H}$-bond \\
\hline & & & Y168 & VL-CDR2 & H-bond \\
\hline & & & Y232 & VL-CDR3 & H-bond \\
\hline D121 & D1153 & Between $\beta$-B2 and $\beta$-C2 & D164 & VL-CDR1 & H-bond \\
\hline S122 & S1154 & Between $\beta$-B2 and $\beta-\mathrm{C} 2$ & D164 & VL-CDR1 & $\mathrm{H}$-bond \\
\hline R123 & $\mathrm{R} 1155$ & Between $\beta$-B2 and $\beta$-C2 & S163 & VL-CDR1 & H-bond \\
\hline & & & D164 & VL-CDR1 & $\mathrm{H}$-bond \\
\hline S125 & S1157 & $\beta-\mathrm{C} 2$ & $\mathrm{R} 50$ & VH-CDR2 & Water bridge \\
\hline L127 & L1159 & $\beta-\mathrm{C} 2$ & W33 & VH-CDR1 & $\mathrm{CH}-\pi$ \\
\hline & & & T52 & VL-CDR2 & H-bond \\
\hline K165 & K1197 & $\beta-\mathrm{F} 2$ & D57 & VL-CDR2 & Water bridge \\
\hline & & & D59 & VL-CDR2 & Salt-bridge \\
\hline & & & Y60 & VL-CDR2 & $\mathrm{H}$-bond \\
\hline & & & W230 & VL-CDR3 & $\mathrm{CH}-\pi$ \\
\hline D. HuscFv34 & & & & & \\
\hline S102 & S1134 & Between $\beta$-F1 and $\beta$-A2 & D57 & VH-CDR1 & $\mathrm{H}$-bond \\
\hline D103 & D1135 & $\beta-\mathrm{A} 2$ & D57 & VH-CDR2 & $\mathrm{H}$-bond \\
\hline $\mathrm{R} 117$ & $\mathrm{R} 1149$ & $\beta-\mathrm{B} 2$ & T58 & VH-CDR2 & H-bond \\
\hline & & & D59 & VH-CDR2 & $\mathrm{H}$-bond \\
\hline R118 & $\mathrm{R} 1150$ & $\beta-\mathrm{B} 2$ & W50 & VH-CDR2 & $\mathrm{CH}-\pi$ \\
\hline $\mathrm{R} 119$ & $\mathrm{R} 1151$ & Between $\beta$-B2 and $\beta$-C2 & D59 & VH-CDR2 & Salt-bridge \\
\hline D121 & D1153 & Between $\beta$-B2 and $\beta-\mathrm{C} 2$ & S101 & $\mathrm{VH}-\mathrm{CDR} 3$ & H-bond \\
\hline & & & D182 & VH-CDR2 & Water bridge \\
\hline & & & $\mathrm{R} 223$ & VL-CDR3 & $\mathrm{H}$-bond \\
\hline
\end{tabular}




\begin{tabular}{|c|c|c|c|c|c|}
\hline \multicolumn{3}{|c|}{ HCV protein } & \multicolumn{2}{|c|}{ HuscFv } & \multirow[t]{2}{*}{ Intermolecular bond } \\
\hline NS3 residue & Polyprotein residue & Motif (-ves) & Amino acid & Domain & \\
\hline S122 & S1154 & Between $\beta$-B2 and $\beta$-C2 & $\mathrm{R} 233$ & VL-CDR3 & H-bond \\
\hline P146 & P1178 & Between $\beta$-D2 and $\beta$-E2 (inside zinc binding site) & Y54 & $\mathrm{VH}-\mathrm{CDR} 2$ & $\mathrm{CH}-\pi$ \\
\hline $\mathrm{T} 147$ & T1179 & Between $\beta$-D2 and $\beta$-E2 (inside zinc binding site) & Y54 & $\mathrm{VH}-\mathrm{CDR} 2$ & $\mathrm{CH}-\pi$ \\
\hline E173 & E1205 & $\alpha$-helix c & K103 & $\mathrm{VH}-\mathrm{CDR} 3$ & H-bond \\
\hline
\end{tabular}

TABLE 6 | Amino acid residues of NS3 within 5 A threshold of van der Waals radii of HuscFvs in Table 2.

\begin{tabular}{ll}
\hline HCV protein & \\
\hline NS3 residue(s) & NS3 motif (-ves) \\
\hline A. HuscFv6 & \\
D19 & Between $\beta$-E1 and $\beta$-F1 \\
G100, S101, S102 & Near the zinc-binding site (C99) \\
D103 & $\beta$-A2 \\
G120 & Between $\beta$-B2 and $\beta$-C2 \\
G124, S125, L126, L127 & $\beta$-C2 \\
R155, V158 & $\beta$-E2 \\
A166, D168, D169 & $\beta$-F2 \\
N174, E176, T177, R178 & $\alpha$-helix C \\
R155, V158 & $\beta$-E2 \\
A166, D168, D169 & $\beta$-F2 \\
N174, E176, T177, R178 & $\alpha$-helix C \\
&
\end{tabular}

\section{B. HuscFv10}

L13

117

A39, Q41

T42, F43

V55

G58, A59

G60, T61, R62

V78, Q80

$\mathrm{R} 123$

I132, S133, L135

$\mathrm{S} 138$

S139

F154, A156, V158, C159

T160, R161

A164, D168

C. HuscFv25

S101

Y105

P115, R118

G120

G124, L126, S128, P129

P146

V158

T160, R161, V163

A166

Between $\beta$-A0 and $\alpha$-helix 0

$\alpha$-helix 0

Between $\beta$-A1 and $\beta$-B1

$\beta-\mathrm{B} 1$

$\beta-\mathrm{C} 1$

$\alpha$-helix a (near the catalytic site, $\mathrm{H} 57$ )

Between $\alpha$-helix a and $\beta$-E1

Between $\beta$-E1 and $\beta-\mathrm{F} 1$ (near catalytic site, D81)

Between $\beta$-B2 and $\beta$-C2 (S6 pocket)

$\alpha$-helix b; L135 is at the S1 pocket

Oxyanion loop

Catalytic triad

$\beta$-E2 (F154 is at the S1 pocket)

Between $\beta$-E2 and $\beta$-F2

$\beta-\mathrm{F} 2$

Near the zinc binding site (C99)

$\beta-\mathrm{A} 2$

$\beta-\mathrm{B} 2$

Between $\beta$-B2 and $\beta$-C2

$\beta-\mathrm{C} 2$

Near the zinc binding site $(\mathrm{C} 145, \mathrm{H} 149)$

$\beta$-E2

Between $\beta$-E2 and $\beta$-F2

$\beta$-F2

\section{HuscFv34}

D79, Q80

C97

T98

C99

G100, S101

G120, R123

S125

C145

$\mathrm{P} 171$

V172, N174, T177

$\mathrm{R} 18$
Between $\beta$-E1 and $\beta$-F1 (near catalytic site, D81)

Zinc-binding site

Between zinc-binding site (C97, C99)

Zinc-binding site

Near zinc-binding site

Between $\beta-\mathrm{B} 2$ and $\beta-\mathrm{C} 2$ (R123 is at the S6 pocket)

$\beta-\mathrm{C} 2$

Zinc-binding site

$\beta-\mathrm{F} 2$

$\alpha$-helix C

Near $\alpha$-helix c
Presumptive residues of the NS3/4A interacted with the HuscFvs were determined by means of computerized homology modeling and intermolecular docking. The lowest local energy of interaction between the HuscFv10 (which was most effective in inhibiting the HCV replication and in restoration of the host innate gene expressions) and the NS3/4A was $-428 \mathrm{kcal} / \mathrm{mol}$, indicating relatively higher affinity on the target binding of this antibody than the other three antibodies. The predictive residues of the NS3/4A protease interacted by the HuscFv10 included several residues critical for the protease activity, i.e., $\mathrm{H} 57$ and D81 of the catalytic triads and K136 and G137 of the oxyanion loop $(54,55)$. Binding of the antibody to the H57 and D81 should inhibit deprotonation of the S139 and, thus, failure of the S139 to mediate a nucleophilic attack of the carbonyl carbon of the scissile bond to form a tetrahedral intermediate containing an oxyanion; therefore, the proteolytic cleavage should not be complete, and, hence, no release of the $\mathrm{N}$ - and $\mathrm{C}$-peptide products from the polyprotein (56). The HuscFv10 might as well disturb the function of the oxyanion loop by docking on the K136 and G137. Moreover, binding of the antibody to the NS4A K20 might as well interfere with the non-covalent interaction between the cofactor (residues 21-34 of NS4A) to the NS3; thus, impaired the cofactor enhancement of the protease activity. Besides, van de Waals force formed by HuscFv10 and several residues of NS3/4A molecule (Table 6) might have additional negative impact on the protease activity. Possibly by causing steric hindrance of the oxyanion hole via the S138, the S1 pocket through interactive atoms at the L135, F154 and nearby residues, i.e., A156, V158, and C159 (54, 55), and the $\mathrm{S} 6$ pocket by means of R123 which is one of the positively charged residues of the $\mathrm{S} 6$ that usually interact with the P6 and P5 residues $(56,57)$.

The HuscFv6 was as effective as the HuscFv10 in inhibiting the $\mathrm{HCV}$ replication. The antibody readily restored the host innate immune response genes from the HCV suppression as did the R9-HuscFv10. From computerized simulation, the lowest local binding energy of this antibody to the NS3/4A was as low as $-356 \mathrm{kcal} / \mathrm{mol}$. However, computerized simulation indicated that the HuscFv6 did not dock on any residues of the catalytic triad, oxyanion hole, or zinc biding site. Instead, the center of interaction of this antibody with the target was at the basic patch of the NS3 protein formed by R117, R118, and R119. Although the role of this cationic patch has not been elucidated, it is likely that residues in this region might form electrostatic interaction with certain negatively charged surface, such as viral RNA. This interaction might mediate pivotal, yet unraveled, activity of the HCV NS3. Binding of the R9-HuscFv6 to these residues might interfere with the activity. Besides, the positively charged residues R123 and K165 of the NS3/4A S6 pocket are believed to 
interact with acidic residues at the P6, and sometimes the P5 also $(57,58)$; blocking of the R123 and K165 by CDR1 and CDR2 of the R9-HuscFv6 VL domain (Table 2) might interfere with the substrate binding of the protease. The HuscFv6 was predicted to form interactive atoms of van de Waals radii with multiple residues of the target (Table 3 ) that might also interfere with the NS3/4A activity by steric hindrance.

The HuscFv25 was the least effective transbody among the four in inhibiting the HCV replication. Computerized intermolecular docking revealed that the antibody also interacted with the protease basic patch (R117, R118, and R119) and S6 pocket residues (R123 and K165) similar to the HuscFv6. However, the local energy that required for binding of this antibody to the target $(-290 \mathrm{kcal} / \mathrm{mol})$ was higher than that of the HuscFv6, which might explain the lower effectiveness of the HuscFv25.

The HuscFv34 interacted with residues of the zinc binding site (C97, C99, C145, P146, and T147), which might cause improper folding of the NS3 and, therefore, deficient in the protease activity $(59,60)$. The antibody also docked on the NS3 basic patch and, thus, might interfere with the important, but still unknown, activity of the NS3 protein.

In conclusion, bacterially derived cell-penetrating human single chain antibodies specific to NS3/4A protein of $\mathrm{HCV}$ produced in this study inhibited replication of the heteologous $\mathrm{HCV}$ (genotype 2a of the pJFH-1) in human hepatic cells and restored expressions of the virally suppressed host innate immune response genes. They were not toxic to human cells and mice. The transbodies have potential for developing and testing further for anti-HCV activity, either alone, in combination with the approved HCV therapeutics, or in a mixture with their cognate specific to other HCV proteins.

\section{ETHICS STATEMENT}

Animal experiments received approval from the Siriraj Bio-safety Risk Management Taskforce (SI 2014-004), Faculty of Medicine

\section{REFERENCES}

1. Suresh S. Hepatitis C virus: molecular biology \& current therapeutic options. Indian J Med Res (2010) 131:17-34.

2. Kota S, Coito C, Mousseau G, Lavergne JP, Strosberg AD. Peptide inhibitors of hepatitis $\mathrm{C}$ virus core oligomerization and virus production. J Gen Virol (2009) 90:1319-28. doi:10.1099/vir.0.008565-0

3. Kota S, Takahashi V, Ni F, Snyder JK, Strosberg AD. Direct binding of a hepatitis $\mathrm{C}$ virus inhibitor to the viral capsid protein. PLoS One (2012) 7:e32207. doi:10.1371/journal.pone.0032207

4. Strosberg AD, Kota S, Takahasjhi V, Snyder JK, Mousseau G. Core as a novel viral target for hepatitis C drug. Viruses (2010) 2:1734-51. doi:10.3390/ v2081734

5. Gao M, Nettles RE, Belema M, Snyder LB, Hguyen VN, Fridel RA, et al. Chemical genetics strategy identifies an HCV NS5A inhibitor with a potent clinical effect. Nature (2010) 65:96-100. doi:10.1038/nature08960

6. Gelman MA, Glenn JS. Mixing the right hepatitis C inhibitor cocktail. Trends Mol Med (2011) 17:34-46. doi:10.1016/j.molmed.2010.10.005

7. Liu X, Huang Y, Cheng M, Pan L, Si Y, Li G, et al. Screening and rational design of hepatitis $\mathrm{C}$ virus entry inhibitory peptides derived from GB virus A NS5A. J Virol (2013) 87:1649-57. doi:10.1128/JVI.02201-12

8. Miller MH, Agarwal K, Austin A, Brown A, Barclay ST, Dundas P, et al. Review article: 2014 UK consensus guidelines - hepatitis $\mathrm{C}$ management and
Siriraj Hospital, Mahidol University, Bangkok 10700, Thailand. The consent procedure used for human participants is not applicable.

\section{AUTHOR CONTRIBUTIONS}

SJ, WS, JT, and KT-i did experiments and prepared figures; RW, supervised SJ on protein purification; WC conceived the project, designed experiments, analyzed data, and wrote the manuscript; PS helped WC on experimental design.

\section{ACKNOWLEDGMENTS}

The authors thank Dr. Takaji Wakita of the Department of Microbiology, Tokyo Metropolitan Institute for Neuroscience, Tokyo, Japan, and Professor Dr. Ralf Batenschlager, Department of Molecular Virology, University of Heidelberg, Germany, for providing the pJFH-1. Huh7 cells were provided by Associate Professor Dr. Thawornchai Limjindaporn, Faculty of Medicine Siriraj Hospital, Mahidol University, Bangkok.

\section{FUNDING}

The work was cosupported by the NSTDA Chair Professor grant (P-1450624) funded by the Crown Property Bureau; DPG5180001 grant of the Thailand Research Fund (TRF); and the National Research University project of the Office of Commission on Higher Education, Thailand. SJ was a scholar of the TRF Royal Golden Jubilee Ph. D. Program.

\section{SUPPLEMENTARY MATERIAL}

The Supplementary Material for this article can be found online at http://journal.frontiersin.org/article/10.3389/fimmu.2016.00318

direct-acting anti-viral therapy. Aliment Pharmacol Ther (2014) 39:1363-75. doi:10.1111/apt.12764

9. Lin MV, Chung R. Recent FDA approval of sofosbuvir and simeprevir. Implications for current HCV treatment. Clin Liver Dis (2014) 3:65-8. doi:10.1002/cld.332

10. Arico-Muendela C, Zhua Z, Dickson H, Parks D, Keicher J, Deng J, et al. Encoded library technology screening of hepatitis C virus NS4B yields a small molecule compound series with in vitro replicon activity. Antimicrob Agents Chemother (2015) 59(6):3450-9. doi:10.1128/AAC.00070-15

11. Lawitz E, Rouzier R, Nguyen T, Nguyen T, Ke J, Praestgaard J, et al. Safety and antiviral efficacy of 14 days of the cyclophilin inhibitor Nim811 in combination with pegylated interferon alpha2a in relapsed genotype $1 \mathrm{HCV}$ infected patients. J Hepatol (2009) 50:S379. doi:10.1016/S0168-8278(09) 61047-3

12. Tang H. Cyclophilin inhibitors as a novel HCV therapy. Viruses (2010) 2:1621-34. doi:10.3390/v2081621

13. Kiser JJ, Flexner C. Direct acting antiviral agents for hepatitis C virus infection. Annu Rev Pharmacol Toxicol (2013) 53:427-49. doi:10.1146/ annurev-pharmtox-011112-140254

14. Cooper C, Lester R, Thorlund K, Druyts E, El Khoury AC, Yaya S, et al. Direct-acting antiviral therapies for hepatitis $\mathrm{C}$ genotype 1 infection: a multiple treatment comparison meta-analysis. Q J Med (2013) 106:153-63. doi:10.1093/qjmed/hcs214 
15. Izquierdo L, Helle F, François C, Castelain S, Duverlie G, Brochot E. Simeprevir for the treatment of hepatitis C virus infection. Pharmgenomics Pers Med (2014) 7:241-9. doi:10.2147/PGPM.S52715

16. Feld JJ, Jacobson IM, Hezode C, Asselah T, Ruane PJ, Gruener N, et al. Sofosbuvir and velpatasvir for HCV genotype 1, 2, 4, 5, and 6 infection. $N$ Engl J Med (2015) 373:2599-607. doi:10.1056/NEJMoa1512610

17. Lin C, Gates CA, Rao BG, Brennan DL, Fulghum JR, Luong YP, et al. In vitro studies of cross-resistance mutations against two hepatitis $C$ virus serine protease inhibitors, VX-950 and BILN2061. J Biol Chem (2005) 280:36784-91. doi:10.1074/jbc.M506462200

18. Manns MP, Wedemeyer H, Cornberg M. Treating viral hepatitis C: efficacy, side effects, and complications. Gut (2006) 55:1350-9. doi:10.1136/ gut.2005.076646

19. Pawlotsky JM. Therapeutic implications of hepatitis $C$ virus resistance to antiviral drugs. Therap Adv Gastroenterol (2009) 2:205-19. doi:10.1177/ 1756283X09336045

20. Bacon BR, Gordon SC, Lawitz E, Marcellin P, Vierling JM, Zeuzem S, et al. Boceprevir for previously treated chronic HCV genotype 1 infection. N Engl J Med (2011) 364:1207-17. doi:10.1056/NEJMoa1009482

21. Wu S, Kanda T, Nagamoto S, Imazeki F, Yokosuka O. Hepatitis C virus protease inhibitor-resistant mutations: our experience and review. World J Gastroenterol (2013) 19:8940-8. doi:10.3748/wjg.v19.i47.8940

22. Dolman CE. Landmarks and pioneers in the control of diphtheria. Can J Public Health (1973) 64:317-36.

23. Deshayes S, Morris MC, Divita G, Heintz F. Cell-penetrating peptides: tools for intracellular delivery of therapeutics. Cell Mol Life Sci (2005) 62:1839-49. doi:10.1007/s00018-005-5109-0

24. Morris MC, Deshayes S, Simeoni F, Aldrien-Herrada G, Heitz F, Divita G. A nonocovalent peptide-based carrier for peptide and short interfering RNA delivery. In: Langel Ü, editor. Cell Penetrating Peptides. Boca Raton, FL: CRC Press (2008). p. 387-408.

25. Heitz F, Morris MC, Divita G. Twenty years of cell-penetrating peptides: from molecular mechanisms to therapeutics. Br J Pharmacol (2009) 157:195-206. doi:10.1111/j.1476-5381.2009.00057.x

26. Morris MC, Deshayes S, Heitz F, Divita G. Cell-penetrating peptides: from molecular mechanisms to therapeutics. Biol Cell (2008) 100:201-17. doi:10.1042/BC20070116

27. Noguchi H, Matsumoto S. Protein transduction technology: a novel therapeutic perspective. Acta Med Okayama (2006) 60:1-11.

28. Snyder EL, Dowdy SF. Recent advances in the use of protein transduction domains for the delivery of peptide, proteins and nucleic acids in vivo. Expert Opin Drug Deliv (2005) 2:43-51. doi:10.1517/17425247.2.1.43

29. Pujals S, Fernandez-Carneado J, Lopez-Iglesias C, Kogan MJ, Giralt E. Mechanistic aspects of CPP-mediated intracellular drug delivery: relevance of CPP-self assembly. Biochim Biophys Acta (2006) 1758:264-79.

30. Noguchi H, Bonner-Weir S, Wei FY, Matsushita M, Matsumoto S. BETA2/ NeuroD protein can be transduced into cells due to an arginine- and lysine-rich sequence. Diabetes (2005) 54:2859-66. doi:10.2337/diabetes.54. 10.2859

31. Phalaphol A, Thueng-in K, Thanongsaksrikul J, Poungpair O, Bangphoomi $\mathrm{K}$, Sookrung $\mathrm{N}$, et al. Humanized-VH/ $\mathrm{V}_{\mathrm{H}} \mathrm{H}$ that inhibit $\mathrm{HCV}$ replication by interfering with the virus helicase activity. J Virol Methods (2013) 194:289-99. doi:10.1016/j.jviromet.2013.08.032

32. Thueng-in K, Thanongsaksrikul J, Srimanote P, Bangphoomi K, Poungpair O, Maneewat $\mathrm{S}$, et al. Cell penetrable humanized- $\mathrm{VH} / \mathrm{V}_{\mathrm{H}} \mathrm{H}$ that inhibit RNA dependent RNA polymerase (NS5B) of HCV. PLoS One (2012) 7:e49254. doi:10.1371/journal.pone.0049254

33. Thueng-in K, Thanongsaksrikul J, Jittavisutthikul S, Seesuay W, Chulanetra M, Sakolvaree $\mathrm{Y}$, et al. Interference of HCV replication by cell penetrable human monoclonal scFv specific to NS5B polymerase. $m A$ s s (2014) 6:1327-39. doi:10.4161/mabs.29978

34. Jittavisutthikul S, Thanongsaksrikul J, Thueng-in K, Chulanetra M, Srimanote $\mathrm{P}$, Seesuay $\mathrm{W}$, et al. Humanized- $\mathrm{V}_{\mathrm{H}} \mathrm{H}$ transbodies that inhibit HCV protease and replication. Viruses (2015) 7:2030-56. doi:10.3390/ v7042030

35. Poungpair O, Pootong A, Maneewatch S, Srimanote P, Tongtawe P, Songserm T, et al. A human single chain transbody specific to matrix protein (M1) interferes with the replication of influenza A virus. Bioconjug Chem (2010) 21:1134-41. doi:10.1021/bc900251u
36. Kulkeaw K, Sakolvaree Y, Srimanote P, Tongtawe P, Maneewatch S, Sookrung N, et al. Human monoclonal ScFv neutralize lethal Thai cobra, Naja kaouthia, neurotoxin. J Proteomics (2009) 72:270-82. doi:10.1016/j.jprot.2008. 12.007

37. Tao T, Ma X, Yang J, Zou JY, Ji SM, Tan YS, et al. Humanized anti-CD25 monoclonal antibody treatment of steroid-refractory acute graft-versus-host disease: a Chinese single-center experience in a group of 64 patients. Blood Cancer J (2015) 5:e308. doi:10.1038/bcj.2015.33

38. Roy A, Kucukural A, Zhang Y. I-TASSER: a unified platform for automated protein structure and function prediction. Nat Protoc (2010) 5:725-38. doi:10.1038/nprot.2010.5

39. Xu D, Zhang Y. Improving the physical realism and structural accuracy of protein models by a two-step atomic-level energy minimization. Biophys $J$ (2011) 101:2525-34. doi:10.1016/j.bpj.2011.10.024

40. Zhang J, Liang Y, Zhang Y. Atomic-level protein structure refinement using fragment-guided molecular dynamics conformation sampling. Structure (2011) 19:1784-95. doi:10.1016/j.str.2011.09.022

41. Kozakov D, Beglov D, Bohnuud T, Mottarella SE, Xia B, Hall DR, et al. How good is automated protein docking? Proteins (2013) 81:2159-66.

42. Bartenschlager R, Ahlborn-Laake L, Mous J, Jaconson H. Kinetics and structure analysis of hepatitis C virus polyprotein processing. J Virol (1994) 68:5045-55.

43. Alexopoulou L, Holt AC, Medzhitov R, Flavell RA. Recognition of double-stranded RNA and activation of NF-kB by Toll-like receptor 3. Nature (2001) 413:732-8. doi:10.1038/35099560

44. Yoneyama M, Kikuchi M, Natsukawa T, Shinobu N, Imaizumi T, Miyagishi $\mathrm{M}$, et al. The RNA helicase RIG-I has an essential function in double-stranded RNA-induced innate antiviral responses. Nat Immunol (2004) 5:730-7. doi:10.1038/ni1087

45. Wang Y, Li J, Wang X, Ye L, Zhou Y, Thomas RM, et al. Hepatitis C virus impairs TLR3 signaling and inhibits IFN- $\lambda \mathrm{I}$ expression in human hepatoma cell line. Innate Immun (2014) 20:3-11. doi:10.1177/1753425913478991

46. Li K, Foy E, Ferreon JC, Nakamura M, Ferreon AN, Ikeda M, et al. Immune evasion by hepatitis $C$ virus NS3/4A protease-mediated cleavage of the toll-like receptor 3 adapter protein TRIF. Proc Natl Acad Sci U S A (2005) 22:2992-7.

47. Li XD, Sun L, Seth RB, Pineda G, Chen Z. Hepatitis C virus protease NS3/4A cleaves mitochondrial antiviral signaling protein of the mitochondria to evade innate immunity. Proc Nat Acad Sci U S A (2005) 102:17717-22.

48. Otsuka M, Kato N, Moriyama M, Taniguchi H, Wang Y, Dharel N, et al. Interaction between the HCV NS3 protein and the host TBK1 protein leads to inhibition of cellular antiviral response. Hepatology (2005) 41:1004-12. doi:10.1002/hep.20666

49. Sakamuro D, Furukawa T, Takegami T. Hepatitis $C$ virus nonstructural protein NS3 transforms NIH 3T3 cells. J Virol (1995) 69:3893-6.

50. Zemel R, Gerechet S, Greif H, Bachmatove L, Birk Y, Golan-Goldhirsh A, et al. Cell transformation induced by hepatitis C virus NS3 serine protease. J Viral Hepat (2001) 8:96-102. doi:10.1046/j.1365-2893.2001.00283.x

51. Tanaka M, Nagano-Fujii M, Deng L, Ishido S, Sada K, Hotta H. Singlepoint mutations of hepatitis C virus NS3 that impair p53 interaction and anti-apoptotic activity of NS3. Biochem Biophys Res Commun (2006) 340:792-9. doi:10.1016/j.bbrc.2005.12.076

52. Fujita T, Ishido S, Muramatsu S, Itoh M, Hotta H. Suppression of actinomycin D-induced apoptosis by the NS3 protein of hepatitis C virus. Biochem Biophys Res Commun (1996) 229:825-8. doi:10.1006/bbrc.1996.1887

53. Rao Dasari VK, Are D, Rao Joginapally V, Mangamoori LN, Rao Adibhatla KSB. Optimization of the downstream process for high recovery of rhG-CSF from inclusion bodies expressed in Escherichia coli. Process Biochem (2008) 43:566-75. doi:10.1016/j.procbio.2008.01.024

54. Love RA, Parge HE, Wickersham JA, Hostomsky Z, Habuka N, Moomaw EW, et al. The crystal structure of the hepatitis C virus NS3 proteinase reveals a trypsin-like fold and a structural zinc binding site. Cell (1996) 87:331-42. doi:10.1016/S0092-8674(00)81350-1

55. Kim JL, Morgenstern KA, Lin C, Fox T, Dwyer MD, Landro JA, et al. Crystal structure of the hepatitis C virus NS3 protease domain complexed with a synthetic NS4A cofactor peptide. Cell (1996) 87:343-55. doi:10.1016/ S0092-8674(00)81351-3

56. Raney KD, Sharma SD, Moustafa I, Cameron CE. Hepatitis C virus non-structural protein 3 (HCV NS3): a multifunctional antiviral target. J Biol Chem (2010) 285:22725-31. doi:10.1074/jbc.R110.125294 
57. Koch U, Biasiol G, Brunetti M, Fattori D, Pallaoro M, Steinkuhler C. Role of charged residues in the catalytic mechanism of hepatitis C virus NS3 protease: electrostatic precollision guidance and transition-state stabilization. Biochemistry (2001) 40:631-40. doi:10.1021/bi002160t

58. Steinkuhler C, Koch U, Narjes F, Matassa VG. Hepatitis C virus protease inhibitors: current progress and future challenge. Curr Med Chem (2001) 8:919-32.

59. De Franscesco R, Urbani A, Nardi MC, Tomei L, Steinkuhler C, Tramontano A. A zinc binding site in viral serine proteinase. Biochemistry (1996) 35:13282-7.

60. Stempniak M, Hostomska Z, Nodes BR, Hostomsky Z. The NS3 proteinase domain of hepatitis C virus is a zinc-containing enzyme. J Virol (1997) 71:2881-6.
Conflict of Interest Statement: The authors declare that the research was conducted in the absence of any commercial or financial relationships that could be construed as a potential conflict of interest.

Copyright $\odot 2016$ Jittavisutthikul, Seesuay, Thanongsaksrikul, Thueng-in, Srimanote, Werner and Chaicumpa. This is an open-access article distributed under the terms of the Creative Commons Attribution License (CC BY). The use, distribution or reproduction in other forums is permitted, provided the original author(s) or licensor are credited and that the original publication in this journal is cited, in accordance with accepted academic practice. No use, distribution or reproduction is permitted which does not comply with these terms. 